\title{
Tumor-Initiating Cells: a criTICal review of isolation approaches and new challenges in targeting strategies
}

\author{
Komal Qureshi-Baig, Pit Ullmann, Serge Haan and Elisabeth Letellier ${ }^{*}$ (D)
}

\begin{abstract}
Most cancers contain a subpopulation of highly tumorigenic cells, known as cancer stem cells (CSCs) or tumor-initiating cells (TICS). Targeting TICs may be essential to achieve cure, because of their self-renewal and tumorigenic properties as well as their resistance to conventional therapies. Despite significant advances in TIC biology, their isolation and identification remain largely disputed and incompletely established. In this review, we discuss the latest developments in isolation and culturing approaches of TICS, with focus on colorectal cancer (CRC). We feature recent findings on TIC-relevant signaling pathways and the metabolic identity of TICS, as well as their current clinical implications. Lastly, we highlight the influence of inter- and intra-tumoral heterogeneity on TIC function and targeting approaches.
\end{abstract}

Keywords: Colorectal cancer, Cancer stem cells, Tumor-initiating cells, Culturing conditions, Surface markers, Spheroid Culture Systems, Metabolic identity, Targeted therapy, Inter- and intra-tumor heterogeneity

\section{Background}

Colorectal cancer (CRC) is one of the most frequently diagnosed cancer types for both men and women and is the third most common cause of cancer mortality in Western countries [1]. Specific alterations in oncogenes and tumor suppressors are associated with the stepwise progression from normal colon mucosa to carcinoma, resulting in a growth and survival advantage of the affected cells. Notably, loss of function mutations in the adenomatous polyposis coli $(A P C)$ tumor suppressor gene on chromosome $5 \mathrm{q} 21$ are known to be among the earliest genetic events to take place in CRC [2]. In fact, loss of $A P C$ leads to a rapid Wnt deregulation and acquisition of a progenitor cell phenotype in the colonic crypt [3]. Although considerable advances have been made on the molecular mechanisms underlying CRC, it is still a matter of debate which mechanisms determine CRC initiation. The discovery of stem cells in colonic crypts supports the hypothesis that normal stem cells might accumulate tumorigenic mutations promoting

\footnotetext{
* Correspondence: elisabeth.letellier@uni.lu

Life Sciences Research Unit, Molecular Disease Mechanisms Group, University of Luxembourg, 6, Avenue du Swing, L-4367, Campus Belval, Belvaux, Luxembourg
}

malignant transformation, especially due to their long lifespan and their capacity to self-renew. In three breakthrough studies that represent a paradigm shift in cancer biology, cell lineage tracing within growing tumors revealed the presence of a tumor-driving subpopulation of cells in glioblastoma [4], squamous skin tumors [5] and intestinal adenomas [6]. In particular, Schepers and colleagues showed that cells positive for leucine-rich repeat-containing G-protein coupled receptor 5 (Lgr5) - a known Wnt target and marker for normal intestinal stem cells [7] - not only contribute to the initial stages of adenoma growth, but also display multipotent stem cell traits as they are able to generate all of the other cell types present in colon adenomas [6]. By tracing the contribution of individual cancer cells to tumor formation, these three studies provide direct experimental evidence supporting the hypothesis that some tumors contain a small population of cells displaying selfrenewal and tumor initiation power, along a vast majority of cells that are non-tumorigenic. This subset of cells is referred to as tumor-initiating cells (TICs), also known as cancer stem cells (CSCs) or CSC-like cells, and can give rise to a heterogeneous population of cells similar in composition to the tumor of origin [8]. Many groups use the term "CSC" that reflects the existence of a cell at the apex of a 
differentiation hierarchy within tumors. We prefer to apply the term "TIC", which represents a functional definition as it refers to the capacity of these cancer cells to induce tumor formation in xenotransplantation studies. The clinical relevance of TICs is further corroborated by recent molecular classification studies, demonstrating that the expression of stem cell and mesenchymal genes denotes a CRC subtype associated with very poor prognosis [9-14].

Despite considerable advances in TIC biology, the isolation and identification of TICs still remain incompletely established. While some studies focus on an antigenic approach, others rely more on functional characteristics that define TICs. In this review, we will comment on the latest developments regarding isolation of colon TICs with focus on tumorspheres, also called spheroid culture (SC) models, derived from patients and cell lines. Additionally, we will discuss different culturing conditions (i.e. serum-containing conditions leading to adherent cultures and serumdeprived conditions favoring growth as spheroids, as well as medium switch experiments) in regard to the maintenance of TIC traits and possible TIC enrichment. Next, key signaling pathways and metabolic mechanisms that are involved in TIC regulation as well as their current clinical implications will be considered. Finally, we will highlight inter- and intra-tumor heterogeneity in cancer and especially in the TIC compartment and speculate how these new findings may impact the development of new TIC-targeting strategies.

\section{Isolation and identification of TICs}

TICs were first described during the 1990's in studies of leukemia stem cells $[15,16]$. A few years later, TICs were also identified in solid tumors of different origins, among which breast [17], skin [18], brain [19, 20], pancreas [21], lung [22] and colon [23, 24]. Controversies still exist concerning the number of TICs within tumors. Indeed, the true frequency of TICs in most human tumors might be underrated due to obstacles encountered in the different techniques, one of the hurdles being the genetic background of the immune-deficient mouse strain used for xenotransplantation assays [25]. Nevertheless, TICs incline to be relatively infrequent in solid tumors [26, 27], although several exceptions exist, such as melanomas in which TICs reach up to $25 \%$ of the tumor population [25]. Within the TIC sub-compartment, the number of tumorigenic cells substantially varies between patients of the same tumor type [27]. Noteworthy, extensive stromal-niche interactions are critical for TIC survival and growth [28]. Thus, to accurately determine TIC frequency in human tumors, more "humanized" models replicating the tumor's natural microenvironment - i.e. including a stromal and immune cell compartment - should be employed in the future [29].
TICs are defined by their self-renewal, differentiation and tumor-initiation capacities. They have been described to propagate tumors that are capable of recapitulating the heterogeneity of primary tumors [23, 24]. Different approaches are used to isolate TICs and while some of them are based on the expression pattern of cell surface markers, others rely more on the functional aspects of TICs. Most importantly, after isolation of the potential TIC-containing population, TICs are ultimately functionally identified based on their self-renewal potential, which is one of the main properties characterizing these cells. These assays have been extensively described $[30,31]$ and are not the focus of this review. Briefly, the self-renewal capacity is assessed in vitro by performing sphere formation assays under clonal conditions (including single-cell assays) and in vivo by transplantation experiments in mice. In the latter setting, limiting dilution assays (LDA) with serial tumor transplantation and subsequent tumor formation in secondary recipients are considered the gold standard in TIC research as they assess the most important biological trait of TICs, i.e. in vivo self-renewal.

\section{The antigenic approach}

The antigenic approach takes advantage of a variety of cell surface markers, such as prominin-1 (commonly known as CD133), CD44, CD24, epithelial-specific antigen (EpCAM/ESA), CD166, CD29 and CD49f, or a combination of them (Tables 1 and 2) [7, 23, 24, 32-39]. Tables 1 and 2 summarize surface markers, either alone or in combination, used to identify colon TICs and illustrate their relevance based on the observed self-renewal capacity of TICs upon sorting for the marker of interest. Examples for markers that gave controversial results are CD133 and Lgr5 (Table 1). Over the last years, many reports have challenged the view of CD133 being a universal TIC marker [40-43]. Importantly, several in vivo studies show that $\mathrm{CD} 133^{+}$and $\mathrm{CD} 133^{-}$cells form tumors with similar efficiency [40,43, 44]. Over the last years, Lgr5 has been revealed as a marker for normal and cancerous intestinal stem cells [7, 45]. Notwithstanding, the role of Lgr5 in CRC remains indistinct; while some studies suggest that intestinal tumors arise from Lgr5-positive cells $[6,45,46]$, Walker and colleagues showed that suppression of Lgr5 expression enhances tumorigenesis [47].

Notably, culturing conditions including cell density and passage number as well as extrinsic factors are suggested to largely influence surface marker expression ([48-51] and cf. next paragraph). Furthermore, there is a large inter-patient variability in the expression of surface markers, with no or small expression to high positivity for the same marker across patients [41, 42, 52-54]. This limited overlap between the phenotype of TICs isolated 
Table 1 Colon TIC markers

\begin{tabular}{|c|c|c|c|c|c|c|}
\hline \multirow[b]{2}{*}{ Marker } & \multirow[b]{2}{*}{ Known function } & \multirow[b]{2}{*}{ References } & \multicolumn{2}{|c|}{$\begin{array}{l}\text { assessment } \\
\text { of self-renewal }\end{array}$} & \multicolumn{2}{|c|}{ cellular system } \\
\hline & & & In vitro & In vivo & cell lines & patients \\
\hline CD133 & Regulation of cell membrane topology & $\begin{array}{l}\text { [O'Brien et al., 2007] } \mathbf{1} \\
\text { [Ricci-Vitiani et al., 2007] } \mathbf{2} \\
\text { [Todaro et al., 2007] } \mathbf{3} \\
\text { [Vermeulen et al., 2008] } \mathbf{4} \\
\text { [Haraguchi et al., 2008] } \mathbf{5} \\
\text { [leta et al., 2008] } \mathbf{6} \\
\text { [Wang et al., 2012] } \mathbf{7} \\
\text { [Shmelkov et al., 2008] } \mathbf{8} \\
\text { [Dittfeld et al., 2009] } \mathbf{9} \\
\text { [Fan et al., 2014] 10 } \\
\text { [Dubash et al., 2016] } \mathbf{1 1} \\
\text { [Qureshi-Baig et al., 2016] } \mathbf{1 2}\end{array}$ & $\begin{array}{l}1 \checkmark \\
2 \checkmark \\
3 \checkmark \\
4 \checkmark \\
6 \checkmark \\
7 \checkmark \\
8- \\
9- \\
10- \\
11- \\
12-\end{array}$ & $\begin{array}{l}1 \checkmark \\
2 \checkmark \\
3 \checkmark \\
4 \checkmark \\
5 \checkmark \\
6 \checkmark \\
8- \\
9- \\
10- \\
11-\end{array}$ & $\begin{array}{l}6 \\
7 \\
9 \\
10\end{array}$ & $\begin{array}{l}3 \\
1 \\
2 \\
4 \\
5 \\
8 \\
10 \\
11 \\
12\end{array}$ \\
\hline LGR5 & Cell adhesion, intestinal stem cell marker & $\begin{array}{l}\text { [Kemper et al., 2012] } \mathbf{1} \\
\text { [Hirsch et al., 2014] } \mathbf{2} \\
\text { [Walker et al., 2011] } \mathbf{3}\end{array}$ & $\begin{array}{l}1 \checkmark \\
2 \checkmark * \\
3-*\end{array}$ & $\begin{array}{l}1 \checkmark \\
2 \checkmark\end{array}$ & $\begin{array}{l}1 \\
2 \\
3\end{array}$ & 1 \\
\hline CD44 & $\begin{array}{l}\text { Cell adhesion and migration, cell-cell interactions, } \\
\text { cell signaling, leukocyte attachment and rolling }\end{array}$ & $\begin{array}{l}\text { [Dalerba et al., 2007] } \mathbf{1} \\
\text { [Vermeulen et al., 2008] } \mathbf{2} \\
\text { [Du et al., 2008] } \mathbf{3} \\
\text { [Haraguchi et al., 2008] } \mathbf{4} \\
\text { [Chu et al., 2009] } \mathbf{5} \\
\text { [Yeung et al., 2010] } \mathbf{6} \\
\text { [Chen et al., 2011] } \mathbf{7} \\
\text { [Wang et al., 2012] } \mathbf{8} \\
\text { [Ohata et al., 2012] } \mathbf{9}\end{array}$ & $\begin{array}{l}2 \checkmark \\
3 \checkmark \\
5 \checkmark \\
6 \checkmark \\
7 \checkmark \\
8 \checkmark \\
9 \checkmark\end{array}$ & $\begin{array}{l}1 \checkmark \\
3 \checkmark \\
4 \checkmark \\
5 \checkmark \\
6 \checkmark \\
7 \checkmark \\
9 \checkmark\end{array}$ & $\begin{array}{l}7 \\
8\end{array}$ & $\begin{array}{l}1 \\
2 \\
3 \\
4 \\
5 \\
6 \\
9\end{array}$ \\
\hline CD44v6 & CD44 variant isoform, cell migration and invasion & [Todaro et al., 2014] 1 & $1 \checkmark$ & & & 1 \\
\hline CD24 & B cell proliferation and maturation & $\begin{array}{l}\text { [Vermeulen et al., 2008] } \mathbf{1} \\
\text { [Yeung et al., 2010] } \mathbf{2} \\
\text { [Ke et al., 2012] } \mathbf{3}\end{array}$ & $\begin{array}{l}1 \checkmark \\
2 \checkmark \\
3 \checkmark\end{array}$ & $\begin{array}{l}2 \checkmark \\
3 \checkmark\end{array}$ & $\begin{array}{l}2 \\
3\end{array}$ & 1 \\
\hline CD166 & Cell adhesion and cell-cell interactions & [Dalerba et al., 2007] 1 & & $1 \checkmark$ & & 1 \\
\hline EpCAM & Cell adhesion, migration, signaling & [Dalerba et al., 2007] 1 & & $1 \checkmark$ & & 1 \\
\hline EphB2 & Position of the different cell types in the crypts & [Merlos-Suárez et al., 2011] 1 & & $1 \checkmark$ & & 1 \\
\hline
\end{tabular}

$\checkmark$ : correlation between self-renewal capacity and expression of surface marker -: no correlation between self-renewal capacity and expression of surface marker

*: studies based on gene silencing

from different patients of the same tumor type most probably reflects the presence of heterogeneous and biologically distinct TIC pools, which might render the identification of TICs difficult and biased. Additionally, as TICs represent a highly dynamic population, it will be important to better understand the influence of the microenvironment on the antigenic profile of TICs. This inter- and intra-tumor heterogeneity as well as its impact on TIC marker expression will further be discussed in the last paragraph of this review.

Several cell surface markers including CD44, CD166 and EpCAM, are players in cell adhesion and attachment, and thus have been thought to favor the survival of tumor cells within the microenvironment [32]. As these markers are not exclusively expressed by TICs [55], but also by other cells, among which stromal cells, their use to isolate TICs from tumor tissue is precarious. Very recently, CD166 was shown to be expressed in stromal progenitor cells within the hematopoietic niche [56]. Furthermore, CD44, which is described to mark colon TICs, includes multiple splice variants. Original TIC isolations were performed by using pan-CD44 antibodies [32], but recently it was shown that full length CD44 is more widely expressed, and that TICs are better identified with the CD44v6 splice variant [57]. Overall, the use of surface markers in the aim to identify and isolate colon TICs remains delicate.

\section{The functional approaches Label-retaining methods}

There are several approaches to identify TICs based on their functional characteristics. TICs are thought to be relatively quiescent, displaying slow proliferative properties, and giving rise to two daughter cells by asymmetric cell division [58]. Thus, TICs can be isolated based on their quiescent traits through the use of lipophilic dyes, such as PKH26 or PKH6. While a cell undergoing a slow division effectively retains the dye, a fast dividing cell rapidly loses or dilutes it from the membrane. TICs retain the dyes for longer periods than the differentiated 
Table 2 Colon TIC marker combinations

\begin{tabular}{|c|c|c|c|c|c|c|}
\hline \multirow{2}{*}{ Marker combinations } & \multirow[b]{2}{*}{ References } & \multicolumn{2}{|c|}{ assessment of self-renewal } & \multicolumn{2}{|c|}{ cellular system } & \multirow[b]{2}{*}{ mouse } \\
\hline & & In vitro & In vivo & cell lines & patients & \\
\hline $\mathrm{CD} 166^{+} / \mathrm{CD}_{4} 4^{+}$ & [Dalerba et al., 2007] 1 & & $1 \checkmark$ & & 1 & \\
\hline $\mathrm{EpCAM}^{\text {high }} / \mathrm{CD} 4^{+}$ & $\begin{array}{l}\text { [Dalerba et al., 2007] } \mathbf{1} \\
\text { [Kai et al., 2009] } \mathbf{2}\end{array}$ & $2 \checkmark$ & $\begin{array}{l}1 \checkmark \\
2 \checkmark\end{array}$ & 2 & 1 & \\
\hline CD24 ${ }^{\text {high }} /{ }^{-C D} 29^{+}$ & [Ghazvini et al., 2013] 1 & & $1 \checkmark$ & & & 1 \\
\hline $\mathrm{CD} 133^{+} / \mathrm{CD}_{4} 4^{+}$ & $\begin{array}{l}\text { [Haraguchi et al., 2008] } 1 \\
\text { [Chen et al., 2011] } 2\end{array}$ & $1 \checkmark$ & $\begin{array}{l}1 \checkmark \\
2 \checkmark\end{array}$ & $\begin{array}{l}1 \\
2\end{array}$ & 1 & \\
\hline $\begin{array}{l}\text { CD133+/CD49f+ } \\
\text { CD44+/CD49f+ }\end{array}$ & [Haraguchi et al., 2013] 1 & & $1 \checkmark$ & & 1 & \\
\hline $\mathrm{CD} 24^{+} / \mathrm{CD} 44^{+}$ & [Yeung et al., 2010] 1 & $1 \checkmark$ & $1 \checkmark$ & 1 & & \\
\hline $\mathrm{CD} 44^{+} / \mathrm{CD} 133^{-}$ & [Wang et al., 2012] 1 & $1 \checkmark$ & & 1 & & \\
\hline $\mathrm{CD} 133^{+} / \mathrm{CD} 24^{+}$ & [Vermeulen et al., 2008] 1 & $1 \checkmark$ & & & 1 & \\
\hline \multicolumn{7}{|l|}{ CD133+/CD24- } \\
\hline \multicolumn{7}{|l|}{ CD133+/CD44- } \\
\hline CD133+/CD44+ & \multirow{3}{*}{$\begin{array}{l}\text { [Vermeulen et al., 2008] } 1 \\
\text { [Haraguchi et al., 2008] } \mathbf{2}\end{array}$} & \multirow{3}{*}{$\begin{array}{l}1- \\
2-\end{array}$} & \multirow{3}{*}{$2-$} & \multirow{3}{*}{2} & \multirow{4}{*}{$\begin{array}{l}1 \\
2\end{array}$} & \\
\hline CD133+/CD166- & & & & & & \\
\hline CD133+/CD166+ & & & & & & \\
\hline \multicolumn{6}{|l|}{ CD166+/CD44+ } & \\
\hline $\mathrm{CD} 24+/ \mathrm{CD} 44+$ & [Muraro et al., 2012] 1 & $1-$ & $1-$ & 1 & & \\
\hline \multicolumn{7}{|l|}{ CD44+/CD166+/EpCAMlow } \\
\hline CD44+/CD166+/EpCAMhigh & [Collura et al., 2013] 1 & $1-$ & & 1 & & \\
\hline $\begin{array}{l}\text { CD133+/CD26+/CD44+ } \\
\text { CD133+/CD26+/CD44- }\end{array}$ & \multirow{5}{*}{ [Pang et al., 2010] 1} & \multirow[t]{4}{*}{$1 \checkmark$} & \multirow[t]{4}{*}{$1 \checkmark$} & & \multirow[t]{4}{*}{1} & \\
\hline \multicolumn{7}{|l|}{ CD133+/CD26-/CD44+ } \\
\hline CD133+/CD26-/CD44- & & & & & & \\
\hline $\begin{array}{l}\text { CD133-/CD26+/CD44+ } \\
\text { CD133-/CD26+/CD44- }\end{array}$ & & & & & & \\
\hline CD133-/CD26-/CD44+ & & & & & & \\
\hline CD133-/CD26-/CD44- & & $1-$ & $1-$ & & 1 & \\
\hline
\end{tabular}

$\checkmark$ : correlation between self-renewal and expression of surface markers

-: no correlation between self-renewal and expression of surface markers

daughter cells $[59,60]$. Bromodeoxyuridine (BrdU) labeling is based on a similar label retention approach. TICs retain more BrdU compared to differentiated cells as it dilutes in dividing cells [39].

\section{Side-population assay}

Another functional trait of TICs is that they display a lower Hoechst dye staining pattern. It is known that an increased expression of membrane proteins of the ATP- binding cassette $(\mathrm{ABC})$ family, which pump various small molecules (such as cytotoxic drugs and dyes) out of cells, is in part responsible for the dye efflux [61]. The resulting fraction displaying a lower Hoechst gradient is called side population (SP). Whereas some studies speculate that SP cells in CRC contain an increased TIC fraction $[62,63]$, others could not associate SP cells with enriched TIC properties, such as clonogenic and multipotent differentiation potential [64]. Over decades, the 
use of SP assays to identify TICs has come along with questionable interpretations (reviewed in [65]). The SP phenotype is not exclusive to stem cells and has also been described in various differentiated cells in adult tissue [66-68]. Thus, caution is required while applying this assay for the identification of TICs. Especially, tumor and stromal cell compartments need to be discriminated and diploid versus aneuploid cell populations should be considered for the analysis [65].

\section{Isolation of TICs based on autofluorescence}

Miranda-Lorenzo and colleagues recently presented a novel strategy for the isolation and identification of TICs across different human tumor types, including CRC [53]. Their approach was based on cells with an autofluorescent subcellular compartment that displayed essential TIC-specific properties, such as self-renewal, long term tumorigenicity and invasiveness in vivo. The distinct autofluorescent population of self-renewing and highly tumorigenic TICs harbored an inherent ability to concentrate the fluorescent vitamin riboflavin in intracellular vesicles that were coated with ATP binding cassette subfamily G member 2 (ABCG2), an ATP-dependent transporter. Even if this small subset of autofluorescent cells display TIC properties, a functional role for the accumulation of riboflavin in autofluorescent vesicles could not be established in regard to TIC biology [53]. This assay might represent a new approach to identify TICs; however, it needs to be validated by other TIC studies. Noteworthy, stromal cells such as macrophages display high autofluorescence [69], which may limit the use of this assay.

\section{Alternative approaches based on the metabolic identity of TICs} An emerging strategy to identify TICs is based on metabolic and bioenergetic differences between TICs and their non-tumorigenic counterparts. Indeed, emerging evidence indicates that cellular metabolism and stemness are strongly intertwined processes [70]. Embryonic and adult stem cells have a reduced number of mitochondria and display a decreased oxygen consumption rate, thereby displaying a rather glycolytic than oxidative metabolite and gene expression signature $[71,72]$. During differentiation, stem cells undergo a "metabolic shift" from active glycolysis to enhanced aerobic mitochondrial respiration [73]. As TICs and stem cells are known to share common properties (i.e. their self-renewal and differentiation abilities), it seems reasonable to assume that TICs are also subject to metabolic reprogramming. Although pancreatic [74] and glioma [75] TICs were found to mainly rely on mitochondrial respiration, many studies on other cancer types, including osteosarcoma [76], melanoma [77], as well as lung [78], breast [79], and liver [80] cancer agree that TICs preferentially display a glycolytic phenotype and reduced mitochondrial activity. Opposing results were found for CRC and hence the metabolic status of colon TICs is still under debate [81]. While Song and colleagues state that high activity of mitochondrial metabolism is required for growth of colon TICs [82], Schell et al. stress that TICs actively suppress oxidative phosphorylation by inhibiting pyruvate import [83].

These conflicting findings may arise from differences in TIC isolation and cultivation techniques; microenvironmental stimuli, such as nutrient starvation, oxidative stress or hypoxia, influence the metabolic state of TICs $[84,85]$. Tumor hypoxia has been shown to further potentiate the glycolytic phenotype of TICs. Besides inducing the expression of glycolytic genes, hypoxia-inducible factor $1 \alpha$ (HIF- $1 \alpha)$, is known to actively suppress mitochondrial respiration by promoting pyruvate dehydrogenase kinase 1 (PDK1), ultimately resulting in repressed pyruvate dehydrogenase (PDH) and reduced TCA cycle activity [86]. Along similar lines, we recently showed that hypoxic culture conditions result in microRNA-210-induced metabolic reprogramming of colon TICs from mitochondrial respiration to increased lactate production. This glycolytic phenotype correlated with enhanced tumorigenicity and self-renewal capacity of colon TICs [85]. Taken together, controversy remains concerning the precise bioenergetic identity of TICs. Thus, a better metabolic characterization of tumorigenic and non-tumorigenic cancer cells may lead to more reliable TIC-specific identification methods in the future.

Another approach relies on the difference in the aldehyde metabolism that exists between TIC and cancer cells. Aldehyde dehydrogenases (ALDHs) are a family of cytosolic isoenzymes that are responsible for oxidizing intracellular aldehydes, leading to the oxidation of retinol to retinoic acid and protecting the organism from damage induced by active aldehydes [87]. In particular the assessment of aldehyde dehydrogenase 1 (ALDH1) activity has been widely used to identify TICs in various cancer types [87]. Although ALDH1 activity assays show controversial results in the context of pancreatic TICs [53], $\mathrm{ALDH}^{+}$CRC cells are reported to display increased TIC traits, especially increased self-renewal capacity and tumorigenicity, compared to the ALDH1 ${ }^{-}$ fraction $[36,41]$.

\section{Spheroid culture systems}

TICs are able to self-renew and display anchorageindependent growth in form of spheroids, a trait that can be used to enrich for TICs in various cancer types $[18,19,21,24,42,52,88-91]$. Most often, 3D in vitro $\mathrm{SC}$ systems that use low-adherent conditions include the use of serum-free medium supplemented with specific growth factors to allow for TIC enrichment. These models are often referred to as tumorspheres or spheroid 
culture (SC) systems, in which differentiated and nonmalignant cells undergo anoikis due to the lack of adherence [92]. Importantly, SC conditions allow to efficiently eliminate non-malignant cell types, such as fibroblasts, that are present in the freshly resected primary tumor tissue and that may outcompete and eventually outgrow cancer cells under serum-containing conditions [23, 24, 42, 43]. This assay has however some disadvantages as it imposes the use of specific culture conditions with consequences on the cancer cell phenotype. Indeed, it is not clear whether the applied conditions select for TICs that originally exist or merely drive cancer cells to adapt a cancer stem cell phenotype. In addition, controversies still exist on whether SCs comprise a homogenous population enriched in undifferentiated cells $[89,93]$ or rather a large range of morphologically different entities, which show inter- and intra-sphere molecular heterogeneity, including variable expression of markers [91, 94]. These questions might soon be addressed by applying modern technologies such as imaging flow cytometry combined with single cell sequencing. Albeit some exceptions exist [95], most studies report that cells derived from SCs display a high selfrenewal capacity in vitro, which correlates with a pronounced tumor-initiating capacity upon injection of low cell doses into immune-depressed mice [24, 42, 96]. Additionally, long-term passaging of cells under spheroid culture conditions further allows for the enrichment in colon TICs over time [42, 91]. Furthermore, SCs have been shown to faithfully preserve key characteristics of the original patient tumors, including gene expression profiles, tumor heterogeneity and tumor morphology, as well as relevant mutations $[24,42,54,88,90,91]$.

\section{Chemoresistance}

TICs have been described to display extensive chemoresistance characteristics. In fact, TICs are able to evade DNA damage by reducing the production of ROS and by enhancing the activity of DNA checkpoint kinases [97, 98]. Furthermore, TICs appear to express high levels of ATPbinding cassette $(\mathrm{ABC})$ transporters, potentially excreting antitumor drugs, and thus contributing to treatment resistance [99-102]. These latter properties represent the underlying principle of the SP assay that has been described earlier. Additionally, functional chemoresistance capacity should be considered as a supplementary feature displayed by TICs, rather than a stringent functional property and thus might not be used as a method for TIC isolation.

\section{Organoids}

Over the last years, intestinal epithelial organoid cultures have emerged as a new system to expand and study intestinal crypts [103]. Organoids allow intestinal stem cells to maintain both their self-renewal capacity and differentiation hierarchy, similar to how it is observed in the adult intestine in vivo. The use of patient-derived organoids from CRC tumors and tumor-associated normal tissue, constituting an ideal matched control, further enables the testing of a range of therapeutic compounds in a patient-relevant model. Finally, longterm organoid cultures of primary CRC cells might prove a suitable system to study colon TIC biology in a more physiologically relevant setting and thus their use may lead to advancement in CRC treatment.

\section{The influence of different culture conditions on TIC traits}

It is still not clear to which extent different culture conditions (i.e. serum-deprived conditions favoring growth as spheroids and serum-containing conditions leading to adherent cultures) influence TIC features. While some studies in CRC could show that self-renewal capacity is increased in SCs compared to adherent counterpart cultures [24, 90], others did observe similar functional properties of TICs between both culturing conditions [41, 104-107]. Calvet and colleagues, suggest that SCs enrich for TICs in a cell line-dependent manner [106]. Colon spheres derived from the Caco- 2 cell line lose several TIC properties compared to their parental adherent counterpart [107]. Similarly, SCs derived from the CRC cell line HCT116, were described to follow a more stochastic than hierarchal organization [108]. These conflicting observations may be explained by the dynamic regulation of TIC properties. Noteworthy, TIC features, including marker expression, are largely influenced by extrinsic factors such as culturing conditions [48-51]. It may be assumed that the loss of expression of a given marker does not alter the tumorigenic potential of TICs. Alternatively, dedifferentiation events could induce the formation of a specific TIC subpopulation with an antigenic profile that is similar to nontumorigenic cells whereas the functional phenotype is retained [109]. In yet another scenario, acquired mutations and clonal evolution of TICs might lead to the generation of specific sub-clones. These subpopulations may show reduced tumorigenic potential while maintaining TIC-like surface marker expression. Modern technologies, such as single cell sequencing or cell lineage tracing, are currently being used to further investigate these issues.

To further interrogate the influence of different culturing conditions on TIC features, we have compared cells derived from traditional CRC cell lines or tumor biopsies, cultured either as SCs (i.e. serum-deprived culture conditions with growth factors) or as regular adherent cultures (i.e. serum-containing culture conditions), respectively [42]. In comparison to adherent counterpart cultures, SC-derived cells display a decreased expression of the differentiation marker CK20 and an increased 
expression of stemness proteins, such as sex determining region Y-box 2 (Sox2), octamer-binding transcription factor 4 (Oct4), Nanog as well as Lgr5, a property which is common to both stem cells and their tumorigenic counterparts [110]. By seeding single cells per well and monitoring sphere formation over time, we demonstrated that SCs derived from traditional CRC cell lines and tumor tissue show high self-renewal capacity. Nevertheless, even after long-term culture in TICenriching conditions, SCs that are transferred to differentiating culture conditions (i.e. serum-containing conditions) still have the capacity to adhere and morphologically resemble differentiated cell populations or the parental cell lines. Likewise, when long-term SCderived adherent differentiated cultures are reversed to TIC conditions (i.e. serum-deprived conditions), they are able to form spheres to a similar extent as the initial SCs [42]. It could further be observed that spheroids and the spheroid-derived adherent differentiated cultures display similar self-renewal capacity and equally form tumors in immune-deficient mice [42, 43]. Additionally, clonal analysis of individual lentivirally marked clones in spheroid cultures and adherent counterparts revealed no systematic differences in contributing clone numbers [43]. These findings suggest that self-renewal and tumor-initiation capacity of TICs might not be restricted to phenotypically immature spheroid cells, and furthermore underlines the high plasticity of cancer cells that are able to reacquire stem-cell traits even after long differentiation processes, a feature that needs to be closely examined for the development of TIC-specific therapies [111] (Fig. 1).

In a study by Collura and colleagues, an extensive characterization of 25 established CRC cell lines was performed and it was shown that SCs do not seem to present enhanced TIC traits in regard to tumor-initiating potential but display chemoresistance ability, compared to adherent cultures [101]. Similarly, we demonstrated that primary SC-derived cells display chemoresistance to 5fluorouracil (5-FU), compared to adherent differentiated cells in different experimental settings [42]. It would now be important to extend these data to an in vivo setting. Interestingly, SCs from established cell lines were more sensitive to chemotherapy than primary SCs derived from patients, highlighting that primary tumorspheres maintain pronounced chemoresistance and thus more closely reflect patient response [42]. It may be speculated that certain observed TIC features, such as higher chemoresistance, are due to phenotypic differences that occur in the TIC compartment over long periods of cell culture. In this context, we have reported that original patient tumor material and primary established cultures share a similar mutational profile, which is also present in the respective adherent counterparts, excluding the possibility that the observed resistance of TICs to chemotherapeutics is due to differences in mutations that have arisen over time or after application of different culture conditions [42]. We might further hypothesize that primary patient-derived $\mathrm{SCs}$ harbor increased expression of $\mathrm{ABC}$ transporters or Lgr5, compared to adherent cultures or to cell-line derived SCs. Alternatively, intra-tumoral heterogeneity might be lost in cell-line derived TIC cultures whereas primary established cultures, used at early passages, could better retain this clinically relevant feature.

Besides differing in means of chemoresistance, SCs further differ from their adherent counterparts in terms of proliferation rate. We observed that spheres derived from differentiated cultures were bigger in size (correlating with a more proliferative phenotype), compared to spheres from SCs. This observation might emphasize the slow-proliferative and potentially stem-like properties of TICs specifically in SCs compared to the adherent counterparts [42], possibly providing SCs with a chemoresistance advantage. Taking the new findings into consideration, SCs seem to represent a superior model to adherent differentiated counterparts for screening of new CRC therapies. The superiority of the SC model is mainly due to the resistance to chemotherapeutics, which is especially retained in primary tumor-derived $\mathrm{SCs}$ and which more closely reflects the therapeutic response observed in patients.

\section{TIC-targeting approaches and clinical implications}

The tumor-initiating and chemoresistant features of TICs highly encourage the development of specific TICtargeting treatments. Conventional cancer therapies do not discriminate between TICs and rapidly growing cancer cells. Whereas temporary regression of the tumor mass might be achieved through targeting differentiated cancer cells, TICs can remain mostly unharmed. New tumors may arise through the tumor-promoting effects of TICs, thereby leading to a rapid relapse of the malignancy. TIC-specific antitumor treatments might be unable to induce rapid shrinkage of the tumor bulk, but instead may eliminate the capacity of TICs for long-term growth, ultimately leading to tumor growth arrest [112].

The identification of differences in metabolic regulation between differentiated cancer cells and TICs has led to the development of several new TIC-specific treatment strategies, such as oxidative stress-based therapies, nitric oxide synthase inhibition, or blockade of aerobic glycolysis [113]. TIC self-renewal is known to be dependent on low levels of ROS [114]. The detoxifying enzyme ALDH1, which is often considered to be a reliable TIC marker, was shown to protect colon TICs against excessive oxidative stress [36]. Accordingly, pharmacological repression of ALDH might kill TICs by selectively inducing ROS production in these cells. 

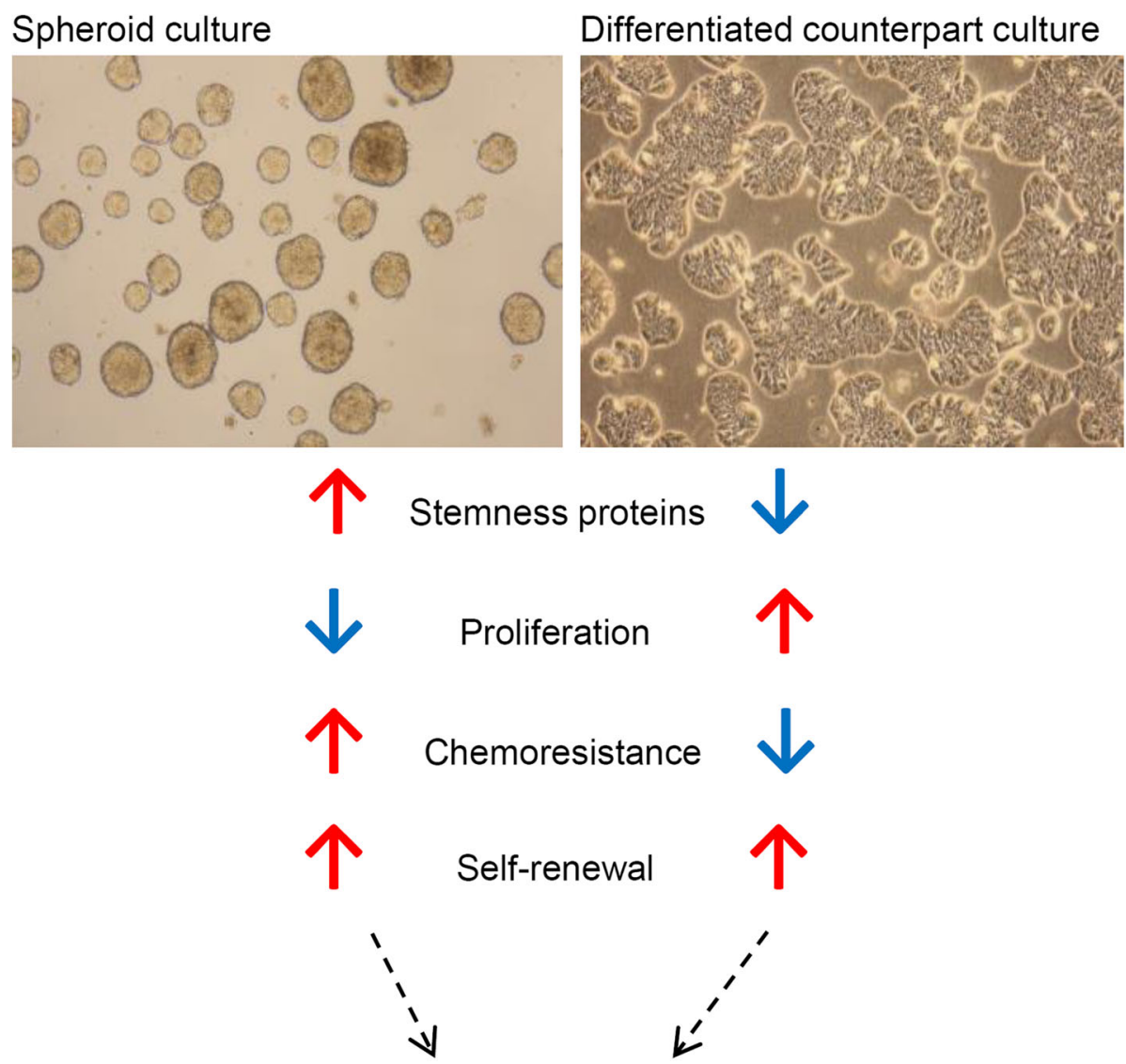

Similar tumor-initiation capacity in immune-deficient mouse

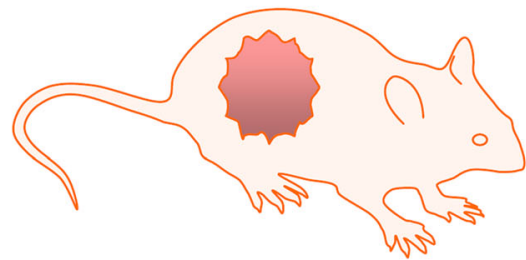

Fig. 1 TICS display pronounced plasticity: self-renewal as well as tumor-initiation capacities of TICs are not restricted to phenotypically immature cells. Spheroid cultures display increased chemoresistance and expression of stemness markers, as well as reduced proliferation, compared to adherent differentiated counterparts. However, both spheroids and adherent counterparts have comparable self-renewal capacities and can lead to similar tumor formation when low cell numbers (10 cells per injection) are injected subcutaneously into immune-deficient mice

Consistently, Chiba et al. could show that the application of disulfiram, a selective ALDH inhibitor, resulted in diminished self-renewal activity and a reduced number of liver TICs [115]. Besides, TICs were shown to display increased nitric oxide (NO) synthesis levels [116] and tumorigenic capacity; and growth of colon TICs could be reduced by using specific inhibitors of inducible nitric oxide synthase (iNOS) [117].

Another promising approach to specifically eradicate TICs might be to target their glycolytic phenotype. The anti-diabetic drug metformin has recently been tested in the context of CRC [118] and strong experimental evidence suggests that metformin, due to its interference with glucose homeostasis, selectively eliminates osteosarcoma [119], glioblastoma [120], and breast [121] TICs. Along the same line, we observed that hypoxia promotes the self-renewal capacity of colon TICs by activating microRNA-210 and by repressing TCA cycle activity [98]. Interestingly, high lactate levels originating from enhanced glycolysis are known to exert several pro-tumorigenic functions. Besides generating an acidic microenvironment, which is commonly associated with increased metastasis formation [122], hypoxia-induced lactate is known to reduce the activity of $\mathrm{pH}$-sensitive $\mathrm{T}$ cells, thereby contributing to the immune evasion of tumor cells [123]. Moreover, high lactate levels are 
thought to generate TICs with a stem cell-like gene expression profile [80]. Importantly, we and others have shown that targeting lactate production efficiently represses the tumorigenic potential of TICs [78, 85], further strengthening the position of lactate as an important oncometabolite and highlighting the therapeutic relevance of glucose metabolism.

TICs display many features of embryonic or tissue stem cells, and preferentially demonstrate persistent activation of one or more highly conserved signal transduction pathways involved in development and tissue homeostasis [124-126] (Table 3). By aiming at the regulation of TIC maintenance and self-renewal processes, it might be possible to target this rare subpopulation $[8,127]$. Accordingly, pathways such as Wnt/ $\beta$-catenin, Notch, TGF- $\beta$, JAK/STAT and Hedgehog, which govern TIC growth and survival, are being addressed for therapeutic purposes [124-127] (Table 4). Wnt ligands that are produced from cells in the stem cell microenvironment serve as a selfrenewal signal for normal stem cells and their tumorigenic counterparts and might therefore be interesting candidates to target TIC-relevant mechanisms [126, 127]. For instance, OMP-18R5, a monoclonal antibody currently in clinical trial phase I, was shown to impair the self-renewal capacity of TICs by targeting the Wnt receptor FZD7 and to inhibit the growth of breast, pancreatic, and colon cancer [128]. Multiple trials involving Wnt/ $\beta$-catenin inhibitors combined with current therapies are in progress (https://clinicaltrials.gov).

An alternative approach to target TICs is to induce their differentiation. For this, bone morphogenetic protein 4 (BMP4) has been described to induce differentiation and to stimulate apoptosis in colon TICs. BMP4 acts by reducing $\beta$-catenin activation through inhibition of the PI3K/AKT pathway and activates Wnt-negative regulators [129, 130]. Similarly, delta-like canonical Notch ligand 4 (DLL4), which is an important

Table 3 Signaling pathways implicated in TIC regulation

\begin{tabular}{lll}
\hline Signaling Pathways & Property & References \\
\hline Wnt/ $\beta$-catenin & Self-renewal & {$[111,126,127,152-155]$} \\
BMI-1 & $\begin{array}{l}\text { Self-renewal, } \\
\text { stemness }\end{array}$ & {$[135,156-158]$} \\
ID1/ID3 & Self-renewal & {$[96,159]$} \\
Hedgehog & Self-renewal, & {$[127,134,160-162]$} \\
& Stemness & \\
Notch & Self-renewal & {$[127,131,132,163-165]$} \\
JAKSTTAT & $\begin{array}{l}\text { Self-renewal, } \\
\text { stemness, }\end{array}$ & {$[138-140,166-171]$} \\
& tumorigenic & \\
& potential & \\
TGF- $\beta$ & EMT, stemness, & {$[10,125,172]$} \\
& dual role in CRC & \\
\hline
\end{tabular}

component of the Notch pathway, contributes to stem cell self-renewal and vascular development. Notch pathway blockade through an anti-DLL4 antibody, which is in clinical trial phase II, has been shown to abolish relapse after chemotherapy in vivo [131, 132].

Another TIC-specific strategy is addressing survival pathways of colon TICs by inhibiting the interleukin 4 (IL-4) signal transduction pathway with an anti-IL-4 neutralizing antibody or an IL-4 receptor alpha antagonist to sensitize TICs to 5-FU and oxaliplatin. This effect was mainly achieved through a down-regulation of antiapoptotic proteins, like cFLIP, BCL-xL and PED [90, 133].

The hedgehog pathway plays a role in maintaining stemness and self-renewal of TICs via the B lymphoma Mo-MLV insertion region 1 homolog, polycomb ring finger (BMI-1) [134], which is known to regulate the self-renewal of TICs in CRC [135]. BMI-1 forms an essential component of the polycomb regulatory complex 1 (PRC1). PRC1 has an important role in the organization of chromatin structure, which, in turn, regulates the expression of genes involved in stem cell behavior [136]. Inhibition of the hedgehog signaling pathway decreases TIC stemness via BMI-1 downregulation and, at the same time, reduces TIC chemoresistance via downregulation of ABCG2 [134]. Furthermore, treatment of primary CRC xenografts with a BMI-1 inhibitor was shown to result in the loss of colon TICs with long-term and irreversible impairment of tumor growth in mice [135].

Along the same lines, inhibitor of DNA binding (ID) 1 and 3 were shown to function together to influence the self-renewal of colon TICs through cell-cycle restriction driven by the cell-cycle inhibitor p21 [96]. Regulation of p21 by ID1 and ID3 was presented as a central mechanism preventing the accumulation of excess DNA damage and subsequent functional exhaustion of TICs in CRC. Furthermore, abolishment of ID1 and ID3 increased sensitivity of these cells to chemotherapy [96].

The Signal Transducer and Activator of Transcription 3 (STAT3), a mediator activated by members of the janus kinase (JAK) family, is known to play a role in the regulation of TICs. STAT3 cooperates together with NANOG and OCT4 and initiates transcription of stemness genes required for modulating pluripotency [137]. The STAT3 signaling pathway is implicated in the clonogenic and tumorigenic potential of prostate [138], colon [139] and breast TICs [140]. ALDH ${ }^{+}$and $\mathrm{CD} 133^{+}$colon TICs exhibit a higher level of STAT3 phosphorylation compared to $\mathrm{ALDH}^{-}, \mathrm{CD} 133^{-}$or unsorted cells [139] and targeting the STAT3 signaling pathway was recently shown to reduce $\mathrm{ALDH}^{+}$breast TICs [140]. In addition, blockade of STAT3 activity leads to the inhibition of tumor growth and tumor-initiating potential in CRC [139].

The transforming growth factor- $\beta$ (TGF- $\beta$ ) signaling pathway is one of the most commonly altered pathways in 
Table 4 TIC-targeting drugs under clinical investigations. Adapted from [81, 125, 173-175]

\begin{tabular}{|c|c|c|c|c|}
\hline Target molecules & Therapeutics & Disease & Clinical trial & Company \\
\hline Undisclosed & TIC inhibitor BB1608 & CRC & $\begin{array}{l}\text { Entering } \\
\text { phase III }\end{array}$ & Boston Biomedicals, Inc \\
\hline Telomerase inhibitor & IMETELSTAT & Broad range & Phase II & Geron Corporation \\
\hline CD133 & Dendritic cell-based vaccine ICT-121 & Glioblastoma & $\begin{array}{l}\text { Entering } \\
\text { phase I }\end{array}$ & $\begin{array}{l}\text { ImmunoCelllular } \\
\text { Therapeutics Ltd }\end{array}$ \\
\hline $\begin{array}{l}\text { Focal adhesion kinase } \\
\text { inhibitor }\end{array}$ & VS6063 & Advanced solid tumors & $\begin{array}{l}\text { Phase I } \\
\text { completed }\end{array}$ & Verastem and Pfeizer \\
\hline Wilms Tumor 1 & Peptides from Wilms Tumor 1 (FPI-01) & $\begin{array}{l}\text { Leukemia and } \\
\text { mesothelioma }\end{array}$ & Phase II & $\begin{array}{l}\text { Formula } \\
\text { Pharmaceuticals }\end{array}$ \\
\hline EphA3 & $\begin{array}{l}\text { Human monoclonal antibody (KB004) binds } \\
\text { EphA3 }\end{array}$ & Leukemia & Phase I & $\begin{array}{l}\text { KaloBios } \\
\text { Pharmaceuticals, Inc. }\end{array}$ \\
\hline \multirow[t]{2}{*}{ Notch pathway } & Anti-DLL4 (demcizumab) (OMP-21 M18) & Solid tumors & Phase II & OncoMed \\
\hline & Anti-Notch2/3 (OPM-59R5) & Solid tumors & Phase I & \\
\hline \multirow[t]{2}{*}{ Wnt pathway } & $\begin{array}{l}\text { Anti-Fzd7 (OMP-18R5, vantictumab, binds } 5 \\
\text { Frizzled receptors) }\end{array}$ & Solid tumors & Phase I & \\
\hline & $\begin{array}{l}\text { Truncated Frizzled 8-Fc fusion protein } \\
\text { (OMP-54 F28) }\end{array}$ & Advanced solid tumors & Phase I & \\
\hline $\begin{array}{l}\text { Undisclosed cancer stem } \\
\text { cell antigen }\end{array}$ & Peptides vaccine (SL401 and SL701) & $\begin{array}{l}\text { Advanced leukemia and } \\
\text { advanced brain cancer }\end{array}$ & $\begin{array}{l}\text { Phase } 1 / \| \\
\text { completed }\end{array}$ & Stemline Therapeutics \\
\hline
\end{tabular}

human cancers. This pathway regulates cell proliferation, differentiation, migration, apoptosis and reportedly stem cell maintenance and function [141]. It is important to mention that TGF- $\beta$ has a dual role and can switch from being a tumor suppressor to a tumor promoter, depending on the cell type and microenvironmental signals [141]. Thus, targeting TGF- $\beta$ signaling for clinical development should be done with caution. Besides, aiming at targeting the immune cell response has emerged as a potential strategy to target TICs in various cancer types. This approach has been used in the context of CRC [142], acute myeloid leukemia (AML) [143] and human bladder cancer [144]. The resulting blockade of the immunoglobulin-like CD47 protein rendered the subpopulation of TICs susceptible to innate and adaptive immune system clearance by restoring phagocytosis by macrophages [143, 144].

\section{Inter- and intra-tumor heterogeneity: future challenges for TIC-specific treatments}

Recent large-scale sequencing studies have revealed different molecular subtypes of CRC [9-14], demonstrating that it is not a uniform disease but a plethora of disparate tumor types and subtypes. This inter-tumoral heterogeneity, consisting of differences between individual patients, presents a significant hurdle to the eradication of cancer and led to the implementation of personalised medicine in the clinics. Besides this interpatient variability, intra-tumor heterogeneity denotes the coexistence of different populations of tumor cells that diverge in their genetic, phenotypic or behavioral characteristics within a given primary tumor [145]. Genetic, epigenetic as well as microenvironmental cues, which favor the growth of some cancer cells and the attrition of others, are thought to be the origin of such intra-tumor heterogeneity $[145,146]$. Furthermore, spatial and temporal heterogeneity are common attributes in CRC and other tumor types. Thus, biopsies of small tumor pieces may not reflect the wide range of alterations found in the tumor as a whole. Altogether, inter- and intra-tumor heterogeneity is thought to largely contribute to therapy failure and disease progression [145]. Latest molecular biology tools, such as barcode sequencing, single cell analysis, lineage tracing, or wholegenome sequencing might help to face the challenge of dissecting both inter- and intratumor heterogeneity.

Recent studies have illustrated that clonal evolution is also occurring within the TIC population itself, with tremendous regulatory impact on self-renewal and tumor-initiation potential [147]. Indeed, mutational analysis of lymphoid leukemia cells demonstrated that individual tumors contain subclones that are genetically different but evolutionarily related [148]. Accordingly, therapeutic targeting of TICs turns out to be more challenging than was initially anticipated, as TICs are not static and genetically homogeneous entities. Along this line, Dieter and colleagues have shown the existence of three different types of TICs in primary human CRC, among which a rare subset of cells that maintain tumor growth in serial transplantation, one subset with limited self-renewal capacity and finally a more latent subtype that is only present in secondary recipients [52]. Additionally, by using lentiviral lineage tracing in combination with in vivo serial transplantation experiments, Kreso and colleagues could detect functional diversity among colon TICs that were derived from the same subclone: while 
some cells displayed long-term self-renewal potential and were detected in every transplant, others were less persistent, losing their proliferative capacity over time [149]. Most intriguing was probably the existence of a dormant subclonal species that became dominant following chemotherapy [149]. It will now be important to link these different functional phenotypes to a genomic and transcriptomic profile. High throughput sequencing platforms will for instance allow clinicians to better understand patient tumors and thus elaborate improved treatment approaches that aim exploiting subclonal-specific alterations. In this regard the organoid technology is of great interest, as recent studies have shown that organoids 1) recapitulate the properties of the original tumor 2) are amenable to highthroughput drug screening and most importantly 3 ) allow for the implementation of personalized medicine [103]. Indeed, multiple organoid cultures can be established from single cells of individual tumor clonal lineages present in the primary tumor [150]. Outgrowing clones may thereby be identified by applying sequencing approaches and treated in vitro with both standard cancer therapies and therapies tailored to the specific genetic program [147]. In the future, this strategy may demonstrate whether individual clones are sensitive to given therapies and could allow clinicians to decide for appropriate follow-up treatment regimens. Such approaches might help to identify and successfully eradicate the totality of pertinent tumor clones, ultimately preventing disease progression and relapse.

Additionally, inter- and intra-tumor heterogeneity arises from the high plasticity of TICs. Indeed, TIC traits, among which the expression of TIC-specific markers, are thought to be reversible. Flow cytometry experiments coupled to Markov model predictions have highlighted that different purified breast cancer cell populations display extensive plasticity and always return to a phenotypic proportion equilibrium over time [151]. In addition, epigenetic changes could directly influence marker expression [49]. Future studies that systematically address the expression of TIC markers, combined with genomic and transcriptomic profile analysis of single cells will help elucidating the controversies regarding TIC markers. Importantly, recent evidence shows that TICs are highly influenced by the tumor microenvironment [28]. Stromal cell-secreted factors, such as Wnt cascade modulators and TGF- $\beta$ signals have been shown to restore the TIC phenotype in more differentiated tumor cells [111], thereby increasing TIC frequency [10], both in vitro and in vivo. These observations are in line with the dynamic model, which suggests that TIC features might get restored in a subset of cells after specific TIC eradication, contributing to disease relapse when therapy is arrested [112]. A better understanding of how TICs interact with their microenvironment will thus be crucial for the successful development of TIC-specific therapies.

\section{Conclusion}

Enormous progresses have been made over the last years in TIC research. However, comprehensive understanding on how to specifically isolate and target the aggressive subset of TICs still needs to improve. Many studies have supported spheroid cultures to be an appropriate mean to enrich for a cell population that displays TIC characteristics. Notwithstanding, xenotransplantation of cells performed in limiting dilution conditions and subsequent tumor formation after serial transplantation in multiple secondary recipients is considered the gold standard in TIC research. Recent evidence illustrates patient-derived spheroid cultures to be a better model to test for CRC therapies than adherent counterparts, not because of enhanced self-renewal potential, but principally because these cultures successfully maintain their resistance to chemotherapeutics. Importantly, several recent studies have unraveled a high plasticity of TICs, a phenomenon that needs to be closely examined for the development of TIC-targeted therapies. Additionally, the metabolic identity of TICs is an emerging field of research and targeting TIC metabolism seems to represent a promising approach for the development of new TICspecific treatments. To conclude, the development of strategies that exploit the unique characteristics of TICs, without neglecting the impact of inter- and intra-tumor heterogeneity, will hopefully result in the specific eradication of TICs, thereby eventually preventing disease progression and recurrence. Lastly, it is important to mention that the CSC and clonal evolution concepts are not, as initially suggested, mutually exclusive and thus efficient therapies will include targeting both populations, the fast-diving tumor cells as well as TICs.

\section{Abbreviations \\ 5-FU: 5-fluorouracil; ABC: ATP-binding cassette; ABCG2: ATP binding cassette subfamily G member 2; ALDH1: Aldehyde dehydrogenase 1 (ALDH1); \\ AML: Acute myeloid leukemia; APC: Adenomatous polyposis coli; BMI-1: B lymphoma Mo-MLV insertion region 1 homolog polycomb ring finger; BMP4: Bone morphogenetic protein 4; BrdU: Bromodeoxyuridine; CRC: Colorectal cancer; CSCs: Cancer stem cells; DLL4: Delta-like canonical Notch ligand 4; EMT: Epithelial to mesenchymal transition; EpCAM/ESA: Epithelial-specific antigen; HIF-1a: Hypoxia-inducible factor 1a; ID: Inhibitor of DNA binding; IL-4: Interleukin 4; iNOS: Inducible nitric oxide synthase; JAK: Janus kinase; PDH: Pyruvate dehydrogenase; PDK1: Pyruvate dehydrogenase kinase 1; PRC1: Polycomb regulatory complex 1 (PRC1); SC: Spheroid culture; SP: Side population; STAT3: Signal Transducer and Activator of Transcription 3; TGF- $\beta$ : transforming growth factor- $\beta$; TIC: Tumor-initiating cell}

\section{Acknowledgements}

The authors thank the Fondation Cancer (grant F1R-LSC-PAU-13HY2C), the Fonds National de la Recherche (FNR) Luxembourg (support of Pit Ullmann and Komal Qureshi-Baig under the AFR grant scheme) and the Fondation du Pélican de Mie and Pierre Hippert-Faber under the aegis of the Fondation de Luxembourg for their financial support. 


\section{Funding}

Fondation Cancer, Fonds National de la Recherche (FNR) Luxembourg and the Fondation du Pélican de Mie and Pierre Hippert-Faber

\section{Availability of data and material}

Not applicable.

\section{Authors' contributions}

$\mathrm{KQB}$ contributed to the collection of data, preparation of the figure and tables, and writing of the manuscript; PU contributed to the collection of data and writing of individual sections of the manuscript; KQB, PU, SH and EL revised and expanded the manuscript. EL conceived the structure of this manuscript and supervised the review. KQB, PU, SH and EL revised the manuscript. EL conceived the structure of this manuscript, supervised and expanded the review. All authors read and approved the final manuscript.

\section{Competing interests}

The authors declare that they have no competing interests.

\section{Consent for publication}

All the authors of this review give their consent for publication.

\section{Ethics approval and consent to participate}

Not applicable.

Received: 25 October 2016 Accepted: 20 January 2017 Published online: 16 February 2017

\section{References}

1. Siegel R, Desantis C, Jemal A. Colorectal Cancer Statistics, 2014. CA Cancer J Clin. 2014;64:104-17

2. Smith G, Carey FA, Beattie J, Wilkie MJV, Lightfoot TJ, Coxhead J, et al. Mutations in APC, Kirsten-ras, and p53-alternative genetic pathways to colorectal cancer. Proc Natl Acad Sci U S A. 2002;99:9433-8. doi:10.1073/ pnas.122612899.

3. Sansom OJ, Reed KR, Hayes AJ, Ireland H, Brinkmann H, Newton IP, et al. Loss of Apc in vivo immediately perturbs Wnt signaling, differentiation, and migration. Genes Dev. 2004;18:1385-90. doi:10.1101/gad.287404.

4. Chen J, Li Y, Yu T-S, McKay RM, Burns DK, Kernie SG, et al. A restricted cell population propagates glioblastoma growth after chemotherapy. Nature. 2012:488:522-6. doi:10.1038/nature11287.

5. Driessens G, Beck B, Caauwe A, Simons BD, Blanpain C. Defining the mode of tumour growth by clonal analysis. Nature. 2012;488:527-30. doi:10.1038/ nature11344.

6. Schepers AG, Snippert HJ, Stange DE, van den Born M, van Es JH, van de Wetering $M$, et al. Lineage tracing reveals $L g r 5+$ stem cell activity in mouse intestinal adenomas. Science. 2012:337:730-5. doi:10.1126/science.1224676.

7. Barker N, van Es JH, Kuipers J, Kujala P, van den Born M, Cozijnsen M, et al. Identification of stem cells in small intestine and colon by marker gene Lgr5. Nature. 2007;449:1003-7. doi:10.1038/nature06196.

8. Visvader JE, Lindeman GJ. Cancer stem cells: Current status and evolving complexities. Cell Stem Cell. 2012;10:717-28. doi:10.1016/j.stem.2012.05.007.

9. Sadanandam A, Wang X, de Sousa E Melo F, Gray JW, Vermeulen L, Hanahan D, et al. Reconciliation of classification systems defining molecular subtypes of colorectal cancer: interrelationships and clinical implications. Cell Cycle. 2014;13:353-7. doi:10.4161/cc.27769.

10. Calon A, Lonardo E, Berenguer-Hergo A, Espinet E, Hernando-momblona X, Iglesias $\mathrm{M}$, et al. Stromal gene expression defines poor-prognosis subtypes in colorectal cancer. Nat Genet. 2015;47:320-9. doi:10.1038/ng.3225.

11. Guinney J, Dienstmann R, Wang X, de Reyniès A, Schlicker A, Soneson C, et al. The consensus molecular subtypes of colorectal cancer. Nat Med. 2015;21:1350-6. doi:10.1038/nm.3967.

12. Sadanandam A, Lyssiotis CA, Homicsko K, Collisson EA, Gibb WJ, Wullschleger $\mathrm{S}$, et al. A colorectal cancer classification system that associates cellular phenotype and responses to therapy. Nat Med. 2013;19:619-25. doi:10.1038/nm.3175.

13. De Sousa E, Melo F, Wang X, Jansen M, Fessler E, Trinh A, de Rooij LPMH, et al. Poor-prognosis colon cancer is defined by a molecularly distinct subtype and develops from serrated precursor lesions. Nat Med. 2013;19: 614-8. doi:10.1038/nm.3174.
14. Marisa L, de Reyniès A, Duval A, Selves J, Gaub MP, Vescovo L, et al. Gene expression classification of colon cancer into molecular subtypes: characterization, validation, and prognostic value. PLoS Med. 2013;10: e1001453. doi:10.1371/journal.pmed.1001453.

15. Lapidot T, Sirard C, Vormoor J, Murdoch B, Hoang T, Caceres-Cortes J, et al. A cell initiating human acute myeloid leukaemia after transplantation into SCID mice. Nature. 1994;367:645-8. doi:10.1038/367645a0.

16. Bonnet D, Dick JE. Human acute myeloid leukemia is organized as a hierarchy that originates from a primitive hematopoietic cell. Nat Med. 1997;3:730-7. doi:10.1038/nm0797-730.

17. Al-Hajj M, Wicha MS, Benito-Hernandez A, Morrison SJ, Clarke MF. Prospective identification of tumorigenic breast cancer cells. Proc Natl Acad Sci U S A. 2003:100:3983-8. doi:10.1073/pnas.0530291100.

18. Fang D, Nguyen TK, Leishear K, Finko R, Kulp AN, Hotz S, et al. A tumorigenic subpopulation with stem cell properties in melanomas. Cancer Res. 2005;65:9328-37. doi:10.1158/0008-5472.CAN-05-1343.

19. Singh SSK, Hawkins C, Clarke ID, Squire JA, Bayani J, Hide T, et al. Identification of human brain tumour initiating cells. Nature. 2004;432 November:396-401. doi:10.1038/nature03128.

20. Hemmati HD, Nakano I, Lazareff JA, Masterman-Smith M, Geschwind DH, Bronner-Fraser $\mathrm{M}$, et al. Cancerous stem cells can arise from pediatric brain tumors. Proc Natl Acad Sci U S A. 2003;100:15178-83.

21. Hermann PC, Huber SL, Herrler T, Aicher A, Ellwart JW, Guba M, et al. Distinct Populations of Cancer Stem Cells Determine Tumor Growth and Metastatic Activity in Human Pancreatic Cancer. Cell Stem Cell. 2007;1:313-23.

22. Bender Kim CF, Jackson EL, Woolfenden AE, Lawrence S, Babar I, Vogel S, et al. Identification of bronchioalveolar stem cells in normal lung and lung cancer. Cell. 2005;121:823-35.

23. O'Brien CA, Pollett A, Gallinger S, Dick JE. A human colon cancer cell capable of initiating tumour growth in immunodeficient mice. Nature. 2007:445:106-10. doi:10.1038/nature05372.

24. Ricci-Vitiani L, Lombardi DG, Pilozzi E, Biffoni M, Todaro M, Peschle C, et al. Identification and expansion of human colon-cancer-initiating cells. Nature. 2007:445:111-5. doi:10.1038/nature05384

25. Quintana E, Shackleton M, Sabel MS, Fullen DR, Johnson TM, Morrison SJ. Efficient tumour formation by single human melanoma cells. Nature. 2008; 456:593-8. doi:10.1038/nature07567.

26. Ishizawa K, Rasheed ZA, Karisch R, Wang Q, Kowalski J, Susky E, et al. Tumorinitiating cells are rare in many human tumors. Cell Stem Cell. 2010;7:279_ 82. doi:10.1016/j.stem.2010.08.009.

27. Stewart JM, Shaw PA, Gedye C, Bernardini MQ, Neel BG, Ailles LE. Phenotypic heterogeneity and instability of human ovarian tumor-initiating cells. Proc Natl Acad Sci. 201 1;108:6468-73. doi:10.1073/pnas.1005529108.

28. Borovski T, De Sousa E Melo F, Vermeulen L, Medema JP. Cancer stem cell niche: the place to be. Cancer Res. 2011;71:634-9. doi:10.1158/0008-5472.CAN-10-3220.

29. Morton JJ, Bird G, Keysar SB, Astling DP, Lyons TR, Anderson RT, et al. XactMice: humanizing mouse bone marrow enables microenvironment reconstitution in a patient-derived xenograft model of head and neck cancer. Oncogene. 2016;35:290-300. doi:10.1038/onc.2015.94.

30. Rycaj K, Tang DG. Cell-of-origin of cancer versus cancer stem cells: assays and interpretations. Cancer Res. 2015;75:4003-11. doi:10.1158/0008-5472.CAN-15-0798.

31. Visvader JE, Lindeman GJ. Cancer stem cells in solid tumours: accumulating evidence and unresolved questions. Nat Rev Cancer. 2008;8:755-68. doi:10.1038/nrc2499.

32. Dalerba P, Dylla SJ, Park I-K, Liu R, Wang X, Cho RW, et al. Phenotypic characterization of human colorectal cancer stem cells. Proc Natl Acad Sci U S A. 2007;104:10158-63. doi:10.1073/pnas.0703478104.

33. Ginestier C, Hur MH, Charafe-Jauffret E, Monville F, Dutcher J, Brown M, et al. $\mathrm{ALDH} 1$ is a marker of normal and malignant human mammary stem cells and a predictor of poor clinical outcome. Cell Stem Cell. 2007;1:555-67. doi:10.1016/j.stem.2007.08.014.

34. Haraguchi N, Ohkuma M, Sakashita H, Matsuzaki S, Tanaka F, Mimori K, et al. CD133 + CD44+ population efficiently enriches colon cancer initiating cells. Ann Surg Oncol. 2008;15:2927-33. doi:10.1245/s10434-008-0074-0.

35. Haraguchi N, Ishii H, Mimori K, Ohta K, Uemura M. CD49f-positive cell population efficiently enriches colon cancer-initiating cells. Int J Oncol. 2013; 43(2):425-30. doi:10.3892/ijo.2013.1955.

36. Huang EH, Hynes MJ, Zhang T, Ginestier C, Dontu G, Appelman H, et al. Aldehyde dehydrogenase 1 is a marker for normal and malignant human colonic stem cells (SC) and tracks SC overpopulation during colon tumorigenesis. Cancer Res. 2009; 69:3382-9. doi:10.1158/0008-5472.CAN-08-4418. 
37. Marquardt JU, Factor VM, Thorgeirsson SS. Epigenetic regulation of cancer stem cells in liver cancer: current concepts and clinical implications. J Hepatol. 2010;53:568-77. doi:10.1016/j.jhep.2010.05.003.

38. Geng S, Guo Y, Wang Q, Li L, Wang J. Cancer stem-like cells enriched with CD29 and CD44 markers exhibit molecular characteristics with epithelial-mesenchymal transition in squamous cell carcinoma. Arch Dermatol Res. 2013;305:35-47.

39. Chu P, Clanton DJ, Snipas TS, Lee J, Mitchell E, Nguyen M-L, et al. Characterization of a subpopulation of colon cancer cells with stem cell-like properties. Int J Cancer. 2009;124:1312-21. doi:10.1002/ijc.24061.

40. Shmelkov S V, Butler JM, Hooper AT, Hormigo A, Kushner J, Milde T, et al. CD133 expression is not restricted to metastatic colon cancer cells initiate tumors. J Clin Invest. 2008;1 18(6):2111-20. doi:10.1172/JCI34401.

41. Fan F, Bellister S, Lu J, Ye X, Boulbes DR, Tozzi F, et al. The requirement for freshly isolated human colorectal cancer (CRC) cells in isolating CRC stem cells. Br J Cancer. 2014;112:539-46. doi:10.1038/bjc.2014.620.

42. Qureshi-Baig K, Ullmann P, Rodriguez F, Frasquilho S, Nazarov PV, Haan S, et al. What Do We learn from spheroid culture systems?insights from tumorspheres derived from primary colon cancer tissue. PLoS One. 2016;11: e0146052. doi:10.1371/journal.pone.0146052.

43. Dubash TD, Hoffmann CM, Oppel F, Giessler KM, Weber S, Dieter SM, et al. Phenotypic differentiation does not affect tumorigenicity of primary human colon cancer initiating cells. Cancer Lett. 2016;371:326-33. doi:10.1016/j. canlet.2015.11.037.

44. Sun X, Jiao X, Pestell TG, Fan C, Qin S, Mirabelli E, et al. MicroRNAs and cancer stem cells: the sword and the shield. Oncogene. 2014;33:4967-77. doi:10.1038/onc.2013.492

45. Hirsch D, Barker N, Mcneil N, Hu Y, Camps J, Mckinnon K, et al. LGR5 positivity defines stem-like cells in colorectal cancer. Carcinogenesis. 2014;35:849-58.

46. Barker N, Ridgway RA, Van Es JH, Van de Wetering M, Begthel H, Van den Born M, et al. Crypt stem cells as the cells-of-origin of intestinal cancer. Nature. 2009;457:608-11.

47. Walker $\mathrm{F}$, Zhang $\mathrm{H}-\mathrm{HH}$, Odorizzi A, Burgess AW. LGR5 is a negative regulator of tumourigenicity, antagonizes wnt signalling and regulates cell adhesion in colorectal cancer cell lines. PLoS One. 2011;6:e22733. doi:10.1371/journal. pone.0022733.

48. Sgambato A, Puglisi MA, Errico F, Rafanelli F, Boninsegna A, Rettino A, et al. Post-translational modulation of CD133 expression during sodium butyrateinduced differentiation of HT29 human colon cancer cells: implications for its detection. J Cell Physiol. 2010;224:234-41. doi:10.1002/jcp.22124.

49. Jeon Y-K, Kim S-H, Choi S-H, Kim K-H, Yoo B-C, Ku J-L, et al. Promoter hypermethylation and loss of CD133 gene expression in colorectal cancers. World J Gastroenterol. 2010;16(25):3153-60. doi:10.3748/WJG.v16.i25.3153.

50. Taïeb N, Maresca M, Guo X-J, Garmy N, Fantini J, Yahi N. The first extracellular domain of the tumour stem cell marker CD133 contains an antigenic ganglioside-binding motif. Cancer Lett. 2009;278:164-73. doi:10. 1016/j.canlet.2009.01.013.

51. Kemper K, Sprick MR, de Bree M, Scopelliti A, Vermeulen L, Hoek M, et al. The AC133 epitope, but not the CD133 protein, is lost upon cancer stem cell differentiation. Cancer Res. 2010;70:719-29. doi:10.1158/0008-5472. CAN-09-1820.

52. Dieter SM, Ball CR, Hoffmann CM, Nowrouzi A, Herbst F, Zavidij O, et al. Distinct types of tumor-initiating cells form human colon cancer tumors and metastases. Cell Stem Cell. 2011:9:357-65.

53. Miranda-Lorenzo, Irene; Dorado, Jorge; Lonardo, Enza; Alcala, Sonia; Serrano, Alicia G.; Clausell-Tormos, Jenifer; Cioffi, Michele; Megias Diego; Zagorac, Sladjana; Balic, Anamaria; Hidalgo, Manuel; Erkan, Mert; Kleeff, Joerg; Scarpa, Aldo; Sainz, Jr., Br C. Intracellular auto-fluorescence - A novel and universally inherited biomarker in epithelial cancer stem cells. Nat Methods. 2014:11.

54. Lee S-H, Hong JH, Park HK, Park JS, Kim B-K, Lee J-Y, et al. Colorectal cancerderived tumor spheroids retain the characteristics of original tumors. Cancer Lett. 2015. doi:10.1016/j.canlet.2015.06.024

55. Kemper K, Grandela C, Medema JP. Molecular identification and targeting of colorectal cancer stem cells. Oncotarget. 2010;1 (6):387-95. https:/www.ncbi. nlm.nih.gov/pmc/articles/PMC3248116/.

56. Hu X, Garcia M, Weng L, Jung X, Murakami JL, Kumar B, et al. Identification of a common mesenchymal stromal progenitor for the adult haematopoietic niche. Nat Commun. 2016;7:13095. doi:10.1038/ncomms13095.

57. Todaro M, Gaggianesi M, Catalano V, Benfante A, lovino F, Biffoni M, et al. CD44v6 Is a Marker of Constitutive and Reprogrammed Cancer Stem Cells Driving Colon Cancer Metastasis. Cell Stem Cell. 2014;14:342-56.
58. Dick JE. Stem cell concepts renew cancer research. Blood. 2008;112:4793-807. doi:10.1182/blood-2008-08-077941

59. Pastò A, Marchesi M, Diamantini A, Frasson C, Curtarello M, Lago C, et al. PKH26 staining defines distinct subsets of normal human colon epithelial cells at different maturation stages. PLoS One. 2012;7.

60. Pece S, Tosoni D, Confalonieri S, Mazzarol G, Vecchi M, Ronzoni S, et al. Biological and molecular heterogeneity of breast cancers correlates with their cancer stem cell content. Cell. 2010;140:62-73. doi:10.1016/j.cell.2009.12.007.

61. Scharenberg CW, Harkey MA, Torok-Storb B. The ABCG2 transporter is an efficient Hoechst 33342 efflux pump and is preferentially expressed by immature human hematopoietic progenitors. Blood. 2002;99:507-12. https://www.ncbi.nlm.nih.gov/pubmed/11781231.

62. Haraguchi N, Utsunomiya T, Inoue H, Tanaka F, Mimori K, Barnard GF, et al. Characterization of a side population of cancer cells from human gastrointestinal system. Stem Cells. 2006:24:506-13. doi:10.1634/stemcells.2005-0282.

63. Xu XT, Xu Q, Tong JL, Zhu MM, Nie F, Chen X, et al. MicroRNA expression profiling identifies miR-328 regulates cancer stem cell-like SP cells in colorectal cancer. Br J Cancer. 2012;106:1320-30. doi:10.1038/bjc.2012.88.

64. Burkert J, Otto WR, Wright NA. Side populations of gastrointestinal cancers are not enriched in stem cells. J Pathol. 2008;214:564-73. doi:10.1002/path.2307.

65. Golebiewska A, Brons NHC, Bjerkvig R, Niclou SP. Critical appraisal of the side population assay in stem cell and cancer stem cell research. Cell Stem Cell. 2011;8:136-47. doi:10.1016/j.stem.2011.01.007.

66. Schinkel. P-Glycoprotein, a gatekeeper in the blood-brain barrier. Adv Drug Deliv Rev. 1999;36:179-94. http://www.ncbi.nlm.nih.gov/pubmed/10837715.

67. Smit JW, Schinkel AH, Weert B, Meijer DK. Hepatobiliary and intestinal clearance of amphiphilic cationic drugs in mice in which both mdr1a and mdr1b genes have been disrupted. Br J Pharmacol. 1998;124:416-24. doi:10. 1038/sj.bjp.0701845.

68. Mayer U, Wagenaar E, Beijnen JH, Smit JW, Meijer DK, van Asperen J, et al. Substantial excretion of digoxin via the intestinal mucosa and prevention of long-term digoxin accumulation in the brain by the mdr 1a P-glycoprotein. Br J Pharmacol. 1996;1 19:1038-44. https://www.ncbi.nlm.nih.gov/pmc/ articles/PMC1915939/.

69. Li F, Yang M, Wang L, Williamson I, Tian F, Qin M, et al. Autofluorescence contributes to false-positive intracellular Foxp3 staining in macrophages: A lesson learned from flow cytometry. J Immunol Methods. 2012;386:101-7. doi:10.1016/j.jim.2012.08.014

70. Menendez JA, Joven J, Cufí S, Corominas-Faja B, Oliveras-Ferraros C, Cuyàs E, et al. The Warburg effect version 2.0: metabolic reprogramming of cancer stem cells. Cell Cycle. 2013;12:1166-79. doi:10.4161/cc.24479.

71. Chen C-T, Hsu S-H, Wei Y-H. Upregulation of mitochondrial function and antioxidant defense in the differentiation of stem cells. Biochim Biophys Acta. 1800;2010:257-63. doi:10.1016/j.bbagen.2009.09.001.

72. Panopoulos AD, Yanes O, Ruiz S, Kida YS, Diep D, Tautenhahn R, et al. The metabolome of induced pluripotent stem cells reveals metabolic changes occurring in somatic cell reprogramming. Cell Res. 2012;22:168-77. doi:10. 1038/cr.2011.177.

73. Chen C-T, Shih Y-R V, Kuo TK, Lee OK, Wei Y-H. Coordinated changes of mitochondrial biogenesis and antioxidant enzymes during osteogenic differentiation of human mesenchymal stem cells. Stem Cells. 2008;26:960-8. doi:10.1634/stemcells.2007-0509.

74. Viale A, Pettazzoni P, Lyssiotis CA, Ying H, Sánchez N, Marchesini M, et al. Oncogene ablation-resistant pancreatic cancer cells depend on mitochondrial function. Nature. 2014;514:628-32. doi:10.1038/nature13611.

75. Vlashi E, Lagadec C, Vergnes L, Matsutani T, Masui K, Poulou M, et al. Metabolic state of glioma stem cells and nontumorigenic cells. Proc Natl Acad Sci U S A. 2011;108:16062-7. doi:10.1073/pnas.1106704108.

76. Palorini R, Votta G, Balestrieri C, Monestiroli A, Olivieri S, Vento R, et al. Energy metabolism characterization of a novel cancer stem cell-like line 3AB-OS. J Cell Biochem. 2014;115:368-79. doi:10.1002/jcb.24671.

77. Bettum IJ, Gorad SS, Barkovskaya A, Pettersen S, Moestue SA, Vasiliauskaite K, et al. Metabolic reprogramming supports the invasive phenotype in malignant melanoma. Cancer Lett. 2015;366:71-83. doi:10.1016/.canlet.2015.06.006.

78. Xie H, Hanai J-I, Ren J-G, Kats L, Burgess K, Bhargava P, et al. Targeting lactate dehydrogenase-a inhibits tumorigenesis and tumor progression in mouse models of lung cancer and impacts tumor-initiating cells. Cell Metab. 2014;19:795-809. doi:10.1016/i.cmet.2014.03.003.

79. Feng W, Gentles A, Nair RV, Huang M, Lin Y, Lee CY, et al. Targeting unique metabolic properties of breast tumor initiating cells. Stem Cells. 2014;32: 1734-45. doi:10.1002/stem. 1662. 
80. Song K, Kwon H, Han C, Zhang J, Dash S, Lim K, et al. Active glycolytic metabolism in CD133 (+) hepatocellular cancer stem cells: regulation by MIR-122. Oncotarget. 2015;6:40822-35. doi:10.18632/oncotarget.5812.

81. Kahlert UD, Mooney SM, Natsumeda M, Steiger H-J, Maciaczyk J. Targeting cancer stem-like cells in glioblastoma and colorectal cancer through metabolic pathways. Int J Cancer. 2016. doi:10.1002/ijc.30259.

82. Song I-S, Jeong YJ, Jeong SH, Heo HJ, Kim HK, Bae KB, et al. FOXM1Induced PRX3 Regulates Stemness and Survival of Colon Cancer Cells via Maintenance of Mitochondrial Function. Gastroenterology. 2015;149: 1006-16.e9. doi:10.1053/j.gastro.2015.06.007.

83. Schell JC, Olson KA, Jiang L, Hawkins AJ, Van Vranken JG, Xie J, et al. A role for the mitochondrial pyruvate carrier as a repressor of the Warburg effect and colon cancer cell growth. Mol Cell. 2014;56:400-13. doi:10.1016/j.molcel. 2014.09.026.

84. Zhang H, Badur MG, Divakaruni AS, Parker SJ, Jäger C, Hiller K, et al. Distinct Metabolic States Can Support Self-Renewal and Lipogenesis in Human Pluripotent Stem Cells under Different Culture Conditions. Cell Rep. 2016;16: 1536-47. doi:10.1016/j.celrep.2016.06.102.

85. Ullmann P, Qureshi-Baig K, Rodriguez F, Ginolhac A, Nonnenmacher $Y$, Ternes D, et al. Hypoxia-responsive miR-210 promotes self-renewal capacity of colon tumor-initiating cells by repressing ISCU and by inducing lactate production. Oncotarget. 2016. doi:10.18632/oncotarget.11772.

86. Kim J, Tchernyshyov I, Semenza GL, Dang CV. HIF-1-mediated expression of pyruvate dehydrogenase kinase: a metabolic switch required for cellular adaptation to hypoxia. Cell Metab. 2006;3:177-85. doi:10.1016/j.cmet.2006.02.002.

87. Xu X, Chai S, Wang P, Zhang C, Yang Y, Yang Y, et al. Aldehyde dehydrogenases and cancer stem cells. Cancer Lett. 2015;369:50-7.

88. Lee J, Kotliarova S, Kotliarov Y, Li A, Su Q, Donin NM, et al. Tumor stem cells derived from glioblastomas cultured in bFGF and EGF more closely mirror the phenotype and genotype of primary tumors than do serum-cultured cell lines. Cancer Cell. 2006;9:391-403. doi:10.1016/j.ccr.2006.03.030.

89. Ponti D. Isolation and In vitro Propagation of Tumorigenic Breast Cancer Cells with Stem/Progenitor Cell Properties. Cancer Res. 2005;65:5506-11.

90. Todaro M, Alea MP, Di Stefano AB, Cammareri P, Vermeulen L, lovino F, et al. Colon cancer stem cells dictate tumor growth and resist cell death by production of interleukin-4. Cell Stem Cell. 2007;1:389-402. doi:10.1016/j. stem.2007.08.001.

91. Vermeulen L, Todaro M, de Sousa MF, Sprick MR, Kemper K, Perez Alea M, et al. Single-cell cloning of colon cancer stem cells reveals a multi-lineage differentiation capacity. Proc Natl Acad Sci U S A. 2008;105:13427-32. doi:10.1073/pnas.0805706105.

92. Weiswald L-B, Bellet $D$, Dangles-Marie $V$. Spherical cancer models in tumor biology. Neoplasia. 2015;17:1-15. doi:10.1016/j.neo.2014.12.004.

93. Dontu G, Abdallah WM, Foley JM, Jackson KW, Clarke MF, Kawamura MJ, et al. In vitro propagation and transcriptional profiling of human mammary stem/progenitor cells. Genes Dev. 2003;17:1253-70.

94. Smart CE, Morrison BJ, Saunus JM, Vargas AC, Keith P, Reid L, et al. In vitro analysis of breast cancer cell line tumourspheres and primary human breast epithelia mammospheres demonstrates inter- and intrasphere heterogeneity. PLoS One. 2013;8, e64388. doi:10.1371/journal.pone.0064388.

95. Barrett LE, Granot Z, Coker C, lavarone A, Hambardzumyan D, Holland EC, et al. Self-renewal does not predict tumor growth potential in mouse models of high-grade glioma. Cancer Cell. 2012;21:11-24. doi:10.1016/..ccr.2011.11.025.

96. O'Brien CA, Kreso A, Ryan P, Hermans KG, Gibson L, Wang Y, et al. ID1 and ID3 regulate the self-renewal capacity of human colon cancer-initiating cells through p21. Cancer Cell. 2012;21:777-92. doi:10.1016/j.ccr.2012.04.036.

97. Bao S, Wu Q, McLendon RE, Hao Y, Shi Q, Hjelmeland AB, et al. Glioma stem cells promote radioresistance by preferential activation of the DNA damage response. Nature. 2006:444:756-60.

98. Diehn M, Cho RW, Lobo NA, Kalisky T, Dorie MJ, Kulp AN, et al. Association of reactive oxygen species levels and radioresistance in cancer stem cells. Nature. 2009:458:780-3. doi:10.1038/nature07733.

99. Matsui W, Wang Q, Barber JP, Brennan S, Smith BD, Borrello l, et al. Clonogenic multiple myeloma progenitors, stem cell properties, and drug resistance. Cancer Res. 2008;68:190-7. doi:10.1158/0008-5472.CAN-07-3096.

100. Ho MM, Ng AV, Lam S, Hung JY. Side population in human lung cancer cell lines and tumors is enriched with stem-like cancer cells. Cancer Res. 2007; 67:4827-33. doi:10.1158/0008-5472.CAN-06-3557.

101. Collura A, Marisa L, Trojan D, Buhard O, Lagrange A, Saget A, et al. Extensive characterization of sphere models established from colorectal cancer cell lines. Cell Mol Life Sci. 2013;70:729-42. doi:10.1007/s00018-012-1160-9.
102. Hashimoto N, Tsunedomi R, Yoshimura K, Watanabe Y, Hazama S, Oka M. Cancer stem-like sphere cells induced from cell lines possess the resistance to anti-cancer drugs. 2014;:1-14.

103. Clevers H. Modeling development and disease with organoids. Cell. 2016; 165:1586-97. doi:10.1016/j.cell.2016.05.082.

104. Muraro MG, Mele V, Daster S, Han J, Heberer M, Cesare Spagnoli G, et al. CD133+, CD166 + CD44+, and CD24 + CD44+ Phenotypes Fail to Reliably Identify Cell Populations with Cancer Stem Cell Functional Features in Established Human Colorectal Cancer Cell Lines. Stem Cells Transl Med. 2012;1:592-603.

105. Ahmad M, Frei K, Willscher E, Stefanski A, Kaulich K, Roth P, et al. How Stemlike Are Sphere Cultures From Long-term Cancer Cell Lines? Lessons From Mouse Glioma Models. 2014;73:1062-77

106. Calvet CY, André FM, Mir LM. The culture of cancer cell lines as tumorspheres does not systematically result in cancer stem cell enrichment. PLoS One. 2014;9:e89644. doi:10.1371/journal.pone.0089644.

107. Wu H, Zhang H, Hu Y, Xia Q, Liu C, Li Y, et al. Sphere formation assay is not an effective method for cancer stem cell derivation and characterization from the Caco-2 colorectal cell line. Curr Stem Cell Res Ther. 2014;9:82-8. https://www.ncbi.nlm.nih.gov/pubmed/24359140.

108. Kai K, Nagano O, Sugihara E, Arima Y, Sampetrean O, Ishimoto T, et al. Maintenance of HCT116 colon cancer cell line conforms to a stochastic model but not a cancer stem cell model. Cancer Sci. 2009;100:2275-82. doi: 10.1111/j.1349-7006.2009.01318.x.

109. Chaffer $\mathrm{CL}$, Weinberg RA. How does multistep tumorigenesis really proceed? Cancer Discov. 2015;5:22-4. doi:10.1158/2159-8290.CD-14-0788.

110. Liu A, Yu X, Liu S. Pluripotency transcription factors and cancer stem cells: Small genes make a big difference. Chin J Cancer. 2013;32:483-7.

111. Vermeulen L, De Sousa E Melo F, Van der Heijden M, Cameron K, De Jong $J \mathrm{H}$, Borovski T, et al. Wnt activity defines colon cancer stem cells and is regulated by the microenvironment. Nat Cell Biol. 2010;12:468-76. doi:10. 1038/ncb2048.

112. Vermeulen L, De Sousa e Melo F, Richel DJ, Medema JP. The developing cancer stem-cell model: Clinical challenges and opportunities. Lancet Oncol. 2012;13:e83-9.

113. Di Francesco AM, Toesca A, Cenciarelli C, Giordano A, Gasbarrini A, Puglisi MA. Metabolic modification in gastrointestinal cancer stem cells: characteristics and therapeutic approaches. J Cell Physiol. 2016;231:2081-7. doi:10.1002/jcp.25318.

114. Ding S, Li C, Cheng N, Cui X, Xu X, Zhou G. Redox regulation in cancer stem cells. Oxid Med Cell Longev. 2015;2015:750798. doi:10.1155/2015/750798.

115. Chiba T, Suzuki E, Yuki K, Zen Y, Oshima M, Miyagi S, et al. Disulfiram eradicates tumor-initiating hepatocellular carcinoma cells in ROS-p38 MAPK pathway-dependent and -independent manners. PLoS One. 2014; 9:e84807. doi:10.1371/journal.pone.0084807.

116. Eyler CE, Wu Q, Yan K, MacSwords JM, Chandler-Militello D, Misuraca KL, et al. Glioma stem cell proliferation and tumor growth are promoted by nitric oxide synthase-2. Cell. 2011;146:53-66. doi:10.1016/j.cell.2011.06.006.

117. Puglisi MA, Cenciarelli C, Tesori V, Cappellari M, Martini M, Di Francesco AM, et al. High nitric oxide production, secondary to inducible nitric oxide synthase expression, is essential for regulation of the tumour-initiating properties of colon cancer stem cells. J Pathol. 2015;236:479-90. doi:10. 1002/path.4545.

118. He J, Wang K, Zheng N, Qiu Y, Xie G, Su M, et al. Metformin suppressed the proliferation of LoVo cells and induced a time-dependent metabolic and transcriptional alteration. Sci Rep. 2015;5:17423. doi:10.1038/srep17423.

119. Chen $X, H u$ C, Zhang W, Shen Y, Wang J, Hu F, et al. Metformin inhibits the proliferation, metastasis, and cancer stem-like sphere formation in osteosarcoma MG63 cells in vitro. Tumour Biol. 2015;36:9873-83. doi:10. 1007/s13277-015-3751-1.

120. Gritti M, Würth R, Angelini M, Barbieri F, Peretti M, Pizzi E, et al. Metformin repositioning as antitumoral agent: selective antiproliferative effects in human glioblastoma stem cells, via inhibition of CLIC1-mediated ion current. Oncotarget. 2014;5:11252-68. doi:10.18632/oncotarget.2617

121. Janzer A, German NJ, Gonzalez-Herrera KN, Asara JM, Haigis MC, Struhl K. Metformin and phenformin deplete tricarboxylic acid cycle and glycolytic intermediates during cell transformation and NTPs in cancer stem cells. Proc Natl Acad Sci U S A. 2014;111:10574-9. doi:10.1073/pnas.1409844111.

122. Martínez-Zaguilán R, Seftor EA, Seftor RE, Chu YW, Gillies RJ, Hendrix MJ. Acidic $\mathrm{pH}$ enhances the invasive behavior of human melanoma cells. Clin Exp Metastasis. 1996;14:176-86. https://www.ncbi.nlm.nih.gov/pubmed/8605731. 
123. Fischer K, Hoffmann P, Voelkl S, Meidenbauer N, Ammer J, Edinger M, et al. Inhibitory effect of tumor cell-derived lactic acid on human T cells. Blood. 2007;109:3812-9. doi:10.1182/blood-2006-07-035972.

124. Dorritie KA, Redner RL, Johnson DE. STAT transcription factors in normal and cancer stem cells. Adv Biol Regul. 2014;56:30-44. doi:10.1016/j.jbior. 2014.05.004.

125. Ajani JA, Song S, Hochster HS, Steinberg IB. Cancer stem cells: the promise and the potential. Semin Oncol. 2015;42:S3-17. doi:10.1053/j.seminoncol. 2015.01.001.

126. De Sousa e Melo F, Vermeulen L. Wnt signaling in cancer stem cell biology. Cancers (Basel). 2016:8:60. doi:10.3390/cancers8070060.

127. Takebe N, Miele L, Harris PJ, Jeong W, Bando H, Kahn M, et al. Targeting Notch, Hedgehog, and Wnt pathways in cancer stem cells: clinical update. Nat Rev Clin Oncol. 2015. doi:10.1038/nrclinonc.2015.61

128. Gurney A, Axelrod F, Bond CJ, Cain J, Chartier C, Donigan L, et al. Wnt pathway inhibition via the targeting of Frizzled receptors results in decreased growth and tumorigenicity of human tumors. Proc Natl Acad Sci U S A. 2012;109:11717-22. doi:10.1073/pnas.1120068109.

129. Catalano V, Gaggianesi M, Spina V, lovino F, Dieli F, Stassi G, et al. Colorectal cancer stem cells and cell death. Cancers (Basel). 2011;3:1929-46. doi:10. 3390/cancers3021929.

130. Lombardo Y, Scopelliti A, Cammareri P, Todaro M, lovino F, Ricci-Vitiani L, et al. Bone morphogenetic protein 4 induces differentiation of colorectal cancer stem cells and increases their response to chemotherapy in mice. Gastroenterology. 2011;140:297-309. doi:10.1053/j.gastro.2010.10.005.

131. Hoey T, Yen W-C, Axelrod F, Basi J, Donigian L, Dylla S, et al. DLL4 blockade inhibits tumor growth and reduces tumor-initiating cell frequency. Cell Stem Cell. 2009:5:168-77. doi:10.1016/j.stem.2009.05.019.

132. Vidal SJ, Rodriguez-Bravo V, Galsky M, Cordon-Cardo C, Domingo-Domenech J. Targeting cancer stem cells to suppress acquired chemotherapy resistance. Oncogene. 2013;33 August:1-13. doi:10.1038/onc.2013.411.

133. Di Stefano AB, lovino F, Lombardo $Y$, Eterno V, Höger $T$, Dieli F, et al. Survivin is regulated by interleukin-4 in colon cancer stem cells. J Cell Physiol. 2010;225:555-61. doi:10.1002/jcp.22238.

134. Huang F-T, Zhuan-Sun Y-X, Zhuang Y-Y, Wei S-L, Tang J, Chen W-B, et al. Inhibition of hedgehog signaling depresses self-renewal of pancreatic cancer stem cells and reverses chemoresistance. Int J Oncol. 2012;41:1707-14. doi:10.3892/ijo.2012.1597.

135. Kreso A, van Galen P, Pedley NM, Lima-Fernandes E, Frelin C, Davis T, et al. Self-renewal as a therapeutic target in human colorectal cancer. Nat Med. 2014;20:29-36. doi:10.1038/nm.3418.

136. Sauvageau M, Sauvageau G. Polycomb group proteins: multi-faceted regulators of somatic stem cells and cancer. Cell Stem Cell. 2010;7:299-313. doi:10.1016/j.stem.2010.08.002.

137. Chambers I. The molecular basis of pluripotency in mouse embryonic stem cells. Cloning Stem Cells. 2004;6:386-91. doi:10.1089/clo.2004.6.386.

138. Kroon P, Berry PA, Stower MJ, Rodrigues G, Mann VM, Simms M, et al. JAK-STAT blockade inhibits tumor initiation and clonogenic recovery of prostate cancer stem-like cells. Cancer Res. 2013;73:5288-98. doi:10. 1158/0008-5472.CAN-13-0874.

139. Lin L, Liu A, Peng Z, Lin H-JJ, Li P-KK, Li C, et al. STAT3 is necessary for proliferation and survival in colon cancer-initiating cells. Cancer Res. 2011;71: 7226-37. doi:10.1158/0008-5472.CAN-10-4660.

140. Xiong A, Yu W, Liu Y, Sanders BG, Kline K. Elimination of ALDH+ breast tumor initiating cells by docosahexanoic acid and/or gamma tocotrienol through SHP-1 inhibition of Stat3 signaling. Mol Carcinog. 2015. doi:10.1002/mc.22291.

141. Jung B, Staudacher JJ, Beauchamp D. Transforming Growth Factor Beta Super Family Signaling in Development of Colorectal Cancer. Gastroenterology. 2016. doi:10.1053/j.gastro.2016.10.015.

142. Todaro M, D'Asaro M, Caccamo N, lovino F, Francipane MG, Meraviglia S, et al. Efficient killing of human colon cancer stem cells by gammadelta $T$ Iymphocytes. J Immunol. 2009;182:7287-96. doi:10.4049/jimmunol.0804288.

143. Majeti R, Chao MP, Alizadeh AA, Pang WW, Jaiswal S, Gibbs KD, et al. CD47 is an adverse prognostic factor and therapeutic antibody target on human acute myeloid leukemia stem cells. Cell. 2009;138:286-99. doi:10.1016/j.cell.2009.05.045.

144. Chan KS, Espinosa I, Chao M, Wong D, Ailles L, Diehn M, et al. Identification, molecular characterization, clinical prognosis, and therapeutic targeting of human bladder tumor-initiating cells. Proc Natl Acad Sci U S A. 2009;106: 14016-21. doi:10.1073/pnas.0906549106.

145. Marusyk A, Almendro V, Polyak K. Intra-tumour heterogeneity: a looking glass for cancer? Nat Rev Cancer. 2012;12:323-34. doi:10.1038/nrc3261.
146. Junttila MR, de Sauvage FJ. Influence of tumour micro-environment heterogeneity on therapeutic response. Nature. 2013;501:346-54. doi:10.1038/nature12626.

147. Apostoli AJ, Ailles L. Clonal evolution and tumor-initiating cells: New dimensions in cancer patient treatment. Crit Rev Clin Lab Sci. 2016;53:40-51. doi:10.3109/10408363.2015.1083944

148. Anderson K, Lutz C, van Delft FW, Bateman CM, Guo Y, Colman SM, et al. Genetic variegation of clonal architecture and propagating cells in leukaemia. Nature. 2011;469:356-61. doi:10.1038/nature09650.

149. Kreso A, O'Brien CA, van Galen P, Gan Ol, Notta F, Brown AM, et al. Variable clonal repopulation dynamics influence chemotherapy response in colorectal cancer. Science. 2013;339:543-8. doi:10.1126/science.1227670.

150. van de Wetering $M$, Francies HE, Francis JM, Bounova G, lorio F, Pronk A et al. Prospective derivation of a living organoid biobank of colorectal cancer patients. Cell. 2015:161:933-45. doi:10.1016/j.cell.2015.03.053.

151. Gupta PB, Fillmore CM, Jiang G, Shapira SD, Tao K, Kuperwasser C, et al. Stochastic state transitions give rise to phenotypic equilibrium in populations of cancer cells. Cell. 2011;146:633-44. doi:10.1016/j.cell.2011.07.026.

152. Giambra V, Jenkins CE, Lam SH, Hoofd C, Belmonte M, Wang X, et al. Leukemia stem cells in T-ALL require active Hif1a and Wnt signaling. Blood. 2015;125:3917-27. doi:10.1182/blood-2014-10-609370.

153. Lin YU, Wu T, Yao Q, Zi S, Cui L, Yang M, et al. LGR5 promotes the proliferation of colorectal cancer cells via the Wnt/B-catenin signaling pathway. Oncol Lett. 2015;9:2859-63. doi:10.3892/ol.2015.3144.

154. Yang L, Tang $H$, Kong $Y$, Xie $X$, Chen J, Song C, et al. LGR5 promotes breast cancer progression and maintains stem-like cells through activation of Wnt/ ß-catenin signaling. Stem Cells. 2015. doi:10.1002/stem.2083.

155. Lee E, Yang J, Ku M, Kim NH, Park Y, Park CB, et al. Metabolic stress induces a Wnt-dependent cancer stem cell-like state transition. Cell Death Dis. 2015; 6:e1805. doi:10.1038/cddis.2015.171.

156. Proctor E, Waghray M, Lee CJ, Heidt DG, Yalamanchili M, Li C, et al. Bmi1 enhances tumorigenicity and cancer stem cell function in pancreatic adenocarcinoma. PLoS One. 2013;8:e55820. doi:10.1371/journal.pone.0055820.

157. Paranjape AN, Balaji SA, Mandal T, Krushik EV, Nagaraj P, Mukherjee G, et al. Bmi1 regulates self-renewal and epithelial to mesenchymal transition in breast cancer cells through Nanog. BMC Cancer. 2014:14:785. doi:10.1186/1471-2407-14-785.

158. Kreso A, Dick JE. Evolution of the cancer stem cell model. Cell Stem Cell. 2014:14:275-91. doi:10.1016/j.stem.2014.02.006.

159. Jin X, Yin J, Kim S-H, Sohn Y-W, Beck S, Lim YC, et al. EGFR-AKT-Smad signaling promotes formation of glioma stem-like cells and tumor angiogenesis by ID3-driven cytokine induction. Cancer Res. 2011;71:7125-34. doi:10.1158/0008-5472.CAN-11-1330.

160. Sims-Mourtada J, Opdenaker LM, Davis J, Arnold KM, Flynn D. Taxane-induced hedgehog signaling is linked to expansion of breast cancer stem-like populations after chemotherapy. Mol Carcinog. 2014. doi:10.1002/mc.22225

161. Justilien V, Fields AP. Molecular pathways: novel approaches for improved therapeutic targeting of Hedgehog signaling in cancer stem cells. Clin Cancer Res. 2015;21:505-13. doi:10.1158/1078-0432.CCR-14-0507.

162. Memmi EM, Sanarico AG, Giacobbe A, Peschiaroli A, Frezza V, Cicalese A, et al. p63 Sustains self-renewal of mammary cancer stem cells through regulation of Sonic Hedgehog signaling. Proc Natl Acad Sci U S A. 2015;112: 3499-504. doi:10.1073/pnas.1500762112.

163. Fender AW, Nutter JM, Bertrand FE, Sigounas G. Notch-1 Promotes Stemness and Epithelial to Mesenchymal Transition in Colorectal Cancer. J Cell Biochem. 2015. doi:10.1002/jcb.25196.

164. Huang R, Wang G, Song Y, Tang Q, You Q, Liu Z, et al. Colorectal cancer stem cell and chemoresistant colorectal cancer cell phenotypes and increased sensitivity to Notch pathway inhibitor. Mol Med Rep. 2015;12: 2417-24. doi:10.3892/mmr.2015.3694

165. Zhang X, Zhao X, Shao S, Zuo X, Ning Q, Luo M, et al. Notch1 induces epithelial-mesenchymal transition and the cancer stem cell phenotype in breast cancer cells and STAT3 plays a key role. Int J Oncol. 2015;46:1141-8. doi:10.3892/ijo.2014.2809

166. Wan S, Zhao E, Kryczek I, Vatan L, Sadovskaya A, Ludema G, et al. Tumorassociated macrophages produce interleukin 6 and signal via STAT3 to promote expansion of human hepatocellular carcinoma stem cells. Gastroenterology. 2014;147:1393-404. doi:10.1053/j.gastro.2014.08.039.

167. Hossain A, Gumin J, Gao F, Figueroa J, Shinojima N, Takezaki T, et al. Mesenchymal stem cells isolated from human gliomas increase proliferation and maintain stemness of glioma stem cells through the IL-6/gp130/STAT3 pathway. Stem Cells. 2015;33:2400-15. doi:10.1002/stem.2053. 
168. Burgos-Ojeda D, Wu R, McLean K, Chen Y-C, Talpaz M, Yoon E, et al. CD24+ ovarian cancer cells Are enriched for cancer-initiating cells and dependent on JAK2 signaling for growth and metastasis. Mol Cancer Ther. 2015;14: 1717-27. doi:10.1158/1535-7163.MCT-14-0607.

169. Thakur R, Trivedi R, Rastogi N, Singh M, Mishra DP. Inhibition of STAT3, FAK and Src mediated signaling reduces cancer stem cell load, tumorigenic potential and metastasis in breast cancer. Sci Rep. 2015;5:10194. doi:10. 1038/srep10194.

170. Won C, Kim B-H, Hee Yi E, Choi K-J, Kim E-K, Jeong J-M, et al. STAT3-mediated CD133 upregulation contributes to promotion of hepatocellular carcinoma. Hepatology. 2015. doi:10.1002/hep.27968

171. Kim BR, Oh SC, Lee D-H, Kim JL, Lee SY, Kang MH, et al. BMP-2 induces motility and invasiveness by promoting colon cancer stemness through STAT3 activation. Tumour Biol. 2015. doi:10.1007/s13277-015-3681-y

172. Mani SA, Guo W, Liao M-J, Eaton EN, Ayyanan A, Zhou AY, et al. The epithelial-mesenchymal transition generates cells with properties of stem cells. Cell. 2008;133:704-15. doi:10.1016/j.cell.2008.03.027.

173. Patricia Ng, Wang Cheng-I. The Dark Side of Pluripotency - Cancer Stem Cell, Pluripotent Stem Cells, Dr. Deepa Bhartiya (Ed.), InTech; 2013. doi:10 5772/54369. Available from: http://www.intechopen.com/books/pluripotentstem-cells/the-dark-side-of-pluripotency-cancer-stem-cell.

174. Sawa M, Masuda M, Yamada T. Targeting the Wnt signaling pathway in colorectal cancer. Expert Opin Ther Targets. 2015;156 April:1-11. doi:10. 1517/14728222.2016.1098619.

175. Li Y, Rogoff HA, Keates S, Gao Y, Murikipudi S, Mikule K, et al. Suppression of cancer relapse and metastasis by inhibiting cancer stemness. Proc Natl Acad Sci U S A. 2015;112:1839-44. doi:10.1073/pnas.1424171112.

\section{Submit your next manuscript to BioMed Central and we will help you at every step:}

- We accept pre-submission inquiries

- Our selector tool helps you to find the most relevant journal

- We provide round the clock customer support

- Convenient online submission

- Thorough peer review

- Inclusion in PubMed and all major indexing services

- Maximum visibility for your research

Submit your manuscript at www.biomedcentral.com/submit 